\title{
Invasive Trichosporon Infection: a Systematic Review on a Re-emerging Fungal Pathogen
}

\begin{abstract}
João N. de Almeida Júnior ${ }^{1,2 *}$ and Christophe Hennequin ${ }^{3,4,5}$
${ }^{1}$ Central Laboratory Division-LIM03, Faculdade de Medicina da Universidade de São Paulo, São Paulo, Brazil, ${ }^{2}$ Laboratory of Medical Mycology-LIM53, Instituto de Medicina Tropical da Universidade de São Paulo, São Paulo, Brazil, ${ }^{3}$ Service de Parasitologie-Mycologie-AP-HP, Hôpital St Antoine, Paris, France, ${ }^{4}$ Institut National de la Santé et de la Recherche Médicale UMR 1135, Centre National de la Recherche Scientifique ERL 8255, Sorbonne Universités, University Pierre and Marie Curie (UPMC), Paris, France, ${ }^{5}$ Centre d'Immunologie et des Maladies Infectieuses, Bd de l'hôpital, Paris, France
\end{abstract}

Objectives: This review aimed to better depict the clinical features and address the issue of therapeutic management of Trichosporon deep-seated infections.

Methods: We comprehensively reviewed the cases of invasive Trichosporon infection reported in the literature from 1994 (date of taxonomic modification) to 2015. Data from antifungal susceptibility testing (AST) studies were also analyzed.

Results: Two hundred and three cases were retained and split into four groups: homeopathy $(n=79)$, other immunodeficiency conditions $(n=41)$, miscellaneous $(n=58)$ and newborns $(n=25)$. Trichosporon asahii was the main causative species (46.7\%) and may exhibit cross-resistance to different antifungal classes. The unfavorable outcome rate was at $44.3 \%$. By multivariate analysis, breakthrough infection (OR 2.45) was associated with unfavorable outcome, whilst the use of an azole-based therapy improved the prognosis (OR 0.16). Voriconazole-based treatment was associated with favorable outcome in hematological patients (73.6 vs. $41.8 \% ; p=0.016$ ). Compiled data from AST demonstrated that (i) T. asahii exhibits the highest MICs to amphotericin B and (ii) voriconazole has the best in vitro efficacy against clinical isolates of Trichosporon spp.

Conclusions: Trichosporon infection is not only restricted to hematological patients. Analysis of compiled data from AST and clinical outcome support the use of voriconazole as first line therapy.

Keywords: Trichosporon species, invasive infection, risk factors, prognosis, diagnosis, treatment, antifungal resistance

\section{INTRODUCTION}

Trichosporon spp. are yeast-like organisms responsible for superficial infection (white piedra), allergic pneumonitis and more rarely, invasive infection (Colombo et al., 2011). In the 1980's, Trichosporon invasive infections (ITI) were considered the second most common cause of fungemia in patients with hematological malignancies (Walsh et al., 1986). However, as triazole derivatives, such as fluconazole, became available, the incidence of those infections decreased (Kaufman et al., 2001; Gomes et al., 2014). On the contrary, maybe due to the breakthrough of the echinocandins, now considered as drugs of choice in many clinical contexts at high-risk for invasive fungal 
infection (IFI), we now deal with a reemergence of this difficult to manage pathogen (Liao et al., 2015). Indeed, the diagnosis of these infections is difficult to anticipate, largely due to the lack of a specific biomarker assay. In addition, identification at the species level is sometimes confusing since the in-depth taxonomic revision of the genus proposed in 1994 (Guého et al., 1994). From then, molecular analyses led to the definition of no less than 50 accepted species within the genus, 17 of which being medically relevant (Hickey et al., 2009; Colombo et al., 2011). Therapeutic management of those infections may also be challenging, since Trichosporon spp. exhibit an intrinsic resistance to the echinocandins and a poor susceptibility to the polyenes (Walsh et al., 1990).

To improve our knowledge of the epidemiology, diagnosis and therapeutic management of those infections, we performed a comprehensive review of the case reports and series published between 1994 and 2015. In addition, we also analyzed studies of in vitro susceptibility testing including a significant number of Trichosporon isolates.

\section{MATERIALS AND METHODS}

\section{Search Strategy and selection Criteria}

We performed by the end of 2015 a systematic search in the Pubmed database using the following key words: "Trichosporon," "trichosporonosis," "invasive infection," “sepsis," "deep-seated infection" and "fungemia." To potentially detect species-specific epidemiological traits, we limited our search after 1994, date of the revised taxonomic classification. We only considered proven invasive infections based on the EORTC-MSG definitions (De Pauw et al., 2008). The cases of probable Trichosporon pneumonia were also considered using the criteria proposed by Colombo et al. (2011). Fungemia and infections involving two non-contiguous organs were considered as disseminated. Data on age, sex, underlying disease, immunological status, and the use of intravenous catheter were collected for each case. Neutropenia was defined as an absolute neutrophil count $\leq 0.5 \times 10^{9}$ neutrophils/L at the time of Trichosporon isolation. Antibiotic therapy was taken into account as a possible predisposing factor when administered for at least 1 week prior to the isolation of Trichosporon. The antifungal therapies initiated either before Trichosporon isolation or used for targeted treatment were analyzed. Removal of intravenous catheter was also recorded. The outcome was considered to be favorable if the patient survived or if the infection was considered as cured at day 30 post-diagnosis.

\section{Antifungal Susceptibility Testing Studies}

We selected in vitro susceptibility testing studies that included $\geq 10$ isolates for a given species and limited our analysis to those having used a microdilution method. Only drugs with an intravenous formulation were retained. Data on echinocandins susceptibility were not included since Trichosporon exhibit natural resistance to these drugs (Espinel-Ingroff, 2003). We also compared antifungal susceptibility profile with the different Trichosporon asahii genotypes.

\section{Statistical Analysis}

Comparisons between groups were performed using Fisher's exact or Chi-square tests when appropriate for the categorical variables. For continuous non-parametric variables, comparisons were made applying the Mann-Whitney $U$-test and the KruskalWallis one-way analysis of variance test. $P$-values of $<0.05$ were considered to be statistically significant. Independent variable found to be associated with death in a univariate analysis with a $p<0.2$, were included in a binary logistic regression analysis. For this part, the level of statistical significance was set at $p<$ 0.05 . For each statistically significant factor, an odds ratio (OR) and $95 \%$ confidence interval (CI) were computed Stata/IC 13.0 for Mac software (StataCorp, College Station, TX 77845, USA).

\section{RESULTS}

In a first instance, we found 537 cases of invasive Trichosporon infection based on a PubMed search limited between 1994 and 2015. The number of reported cases of invasive Trichosporon infections (ITI) grew significantly through the years, from 139 (25.8\%) in the 1994-2004 to $398(74.2 \%)$ between the 2005 and 2015 period (Chi-square test; $p<0.001$ ). Three hundred and thirty-four cases, mainly recorded in series, were excluded because of insufficient data (Figure 1).

Among the 203 cases retained, 199 cases were proven infection, whereas four were considered probable infection. Excluding newborns (25 cases), the median age of those patients was 41.6 years, but the range varied from 3 days of life to 85 years. The sex ratio was calculated at 0.56 .

For comparison analysis, the cases were clustered according to the main underlying disease, e.g., homeopathy $(n=79$; Grauer et al., 1994; Higgins et al., 1994; Hsiao et al., 1994; Nasu et al., 1994; Hung et al., 1995; Spánik et al., 1995; Itoh et al., 1996; Fanci et al., 1997; Kataoka-Nishimura et al., 1998; Sklair-Levy et al., 1998; Krcmery et al., 1999; Takamura et al., 1999; Erer et al., 2000; Kim et al., 2001; Moretti-Branchini et al., 2001; Fournier et al., 2002; Hadley et al., 2002; Meyer et al., 2002; Chang et al., 2003; Marty et al., 2003; Bassetti et al., 2004; Chowdhary et al., 2004; Viscomi et al., 2004; Antachopoulos et al., 2005; ChanTack, 2005; Akagi et al., 2006; Ghiasian et al., 2006; Kendirli et al., 2006; Koyanagi et al., 2006; Matsue et al., 2006; MeguroHashimoto et al., 2006; Rodrigues et al., 2006; Hara et al., 2007; Miura et al., 2007; Rieger et al., 2007; Bayramoglu et al., 2008; Hosoki et al., 2008; Thibeault et al., 2008; Tsuji et al., 2008; Fekkar et al., 2009; Walia et al., 2009; Gabriel et al., 2011; Kudo et al., 2011; Hosokawa et al., 2012; Menezes et al., 2012; Chen et al., 2014; Issarachaikul et al., 2014; Karapinar et al., 2014; Capoor et al., 2015; Odero et al., 2015; Pérard et al., 2015; Tanyildiz et al., 2015), other immunodeficiency conditions ( $n=41$; Canales et al., 1998; Lascaux et al., 1998; Anuradha et al., 2000; Piwoz et al., 2000; Ebright et al., 2001; Abliz et al., 2002; Chakrabarti et al., 2002; Kahana et al., 2003; Nettles et al., 2003; Wynne et al., 2004; Abdala et al., 2005; Gunn et al., 2006; Karabay et al., 2006; Rodrigues et al., 2006; Biasoli et al., 2008; David et al., 2008; Gross and Kan, 2008; Chagas-Neto et al., 2009; Lacasse and Cleveland, 2009; Servonnet et al., 2010; Fadhil et al., 2011; Macêdo et al., 


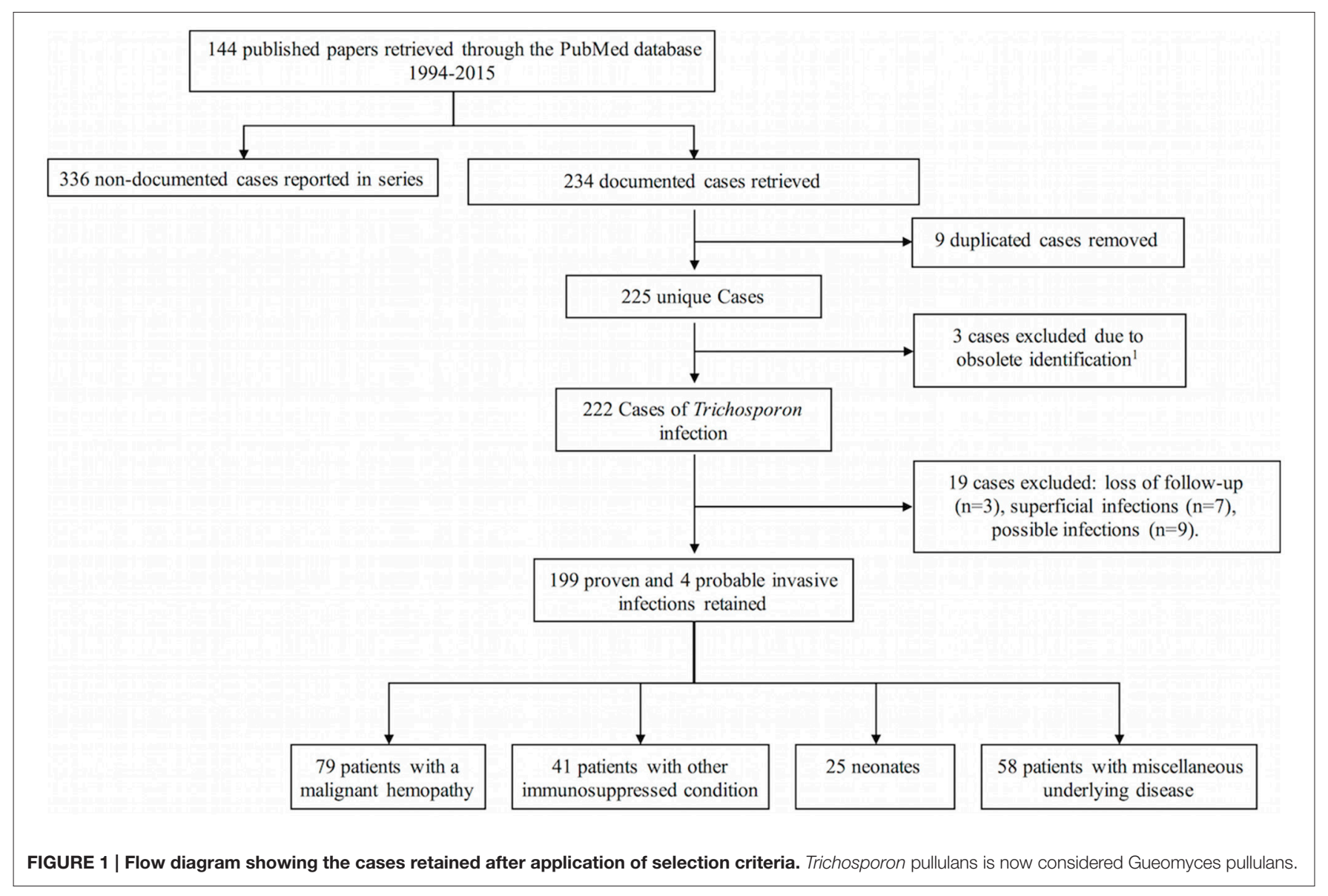

2011; Songcharoen et al., 2011; Basiri et al., 2012; Hirschi et al., 2012; Ogura et al., 2012; Tsai et al., 2012; Chen et al., 2013; Almeida Júnior et al., 2014; Yang et al., 2014; Chaitanya et al., 2015; Nobrega de Almeida Júnior et al., 2015; Ozkaya-Parlakay et al., 2016), miscellaneous ( $n=58$; De Saedeleer et al., 1994; Lopes et al., 1994, 1995, 1997; Miralles et al., 1994, p. 10; Miró et al., 1994; Sidarous et al., 1994; Still et al., 1994; Hajjeh and Blumberg, 1995; Mathews and Prabhakar, 1995; Melez et al., 1995; Chaumentin et al., 1996; Kouppari et al., 1997; Wang and Lin, 1999; Cawley et al., 2000; Lo Passo et al., 2001; Mooty et al., 2001; Wolf et al., 2001; Chitra et al., 2002; Kustimur et al., 2002; Reddy et al., 2002; Crowther et al., 2003; Madariaga et al., 2003; Spirn et al., 2003; Ramos et al., 2004; O'Gorman et al., 2006; Rodrigues et al., 2006; Kim et al., 2007, 2008; Tian et al., 2007; Fagundes Júnior et al., 2008; Jian et al., 2008; Chagas-Neto et al., 2009; Hickey et al., 2009; Izumi et al., 2009; Shang et al., 2010; Slocumb et al., 2010; Heslop et al., 2011; Tsai et al., 2011; Liao et al., 2012; Padhi et al., 2014; Gonul et al., 2015; Kumar et al., 2015; Negi et al., 2015; Zuo et al., 2015) and newborns ( $n=25$; Yoss et al., 1997; Sweet and Reid, 1998; Gökahmetoğlu et al., 2002; Panagopoulou et al., 2002; Salazar and Campbell, 2002; Yildiran et al., 2003; Maheshwari et al., 2004; Chagas-Neto et al., 2009; Pereira et al., 2009; Vashishtha et al., 2012; Basu et al., 2015). The main clinical characteristics of each group are summarized in Table 1 and are detailed in Tables S1-S4.

\section{Clinical Presentation of ITIs}

The main clinical presentations of 203 cases of ITI are summarized in Table 1. Among the 199 cases of proven infection, dissemination was reported in 162 cases (79.8\%) mainly due to fungemia ( $n=151,93.2 \%)$. Blood was the unique site of isolation in 90 cases. In other cases, the patients presented mainly with skin $(n=13)$, lungs $(n=17)$, skin and lungs $(n=14)$, liver and/or spleen $(n=10)$, brain $(n=4)$, eyes $(n=3)$ involvement. In eleven patients without fungemia, disseminated trichosporonosis was diagnosed based on the involvement of the skin $(n=3)$, skin and brain $(n=3)$, skin and lungs $(n=2)$, skin and digestive tract $(n=$ $1)$, skin and liver $(n=1)$, heart valve and embolic material/skin $(n=1)$. In the case of proven localized deep-seated infection $(n=37)$, the following organs were predominantly involved: peritoneum $(n=14)$, lower respiratory tract $(n=8)$, brain $(n$ $=3)$, eye $(n=3)$, esophagus $(n=3)$. Finally, four probable Trichosporon pulmonary infections were retained.

\section{Patients with Hematologic Disease $(n=79)$}

Acute myeloid leukemia $(n=40 ; 50.6 \%)$ was the most frequent underlying disease in this group of patients, followed by acute lymphoid leukemia $(n=17)$ and myelodysplasic syndrome $(n$ $=5$ ). Sixty-seven of those patients $(84.8 \%)$ were neutropenic at the time of diagnosis of the Trichosporon infection. Eight patients $(10.1 \%)$ developed invasive trichosporonosis after a 
TABLE 1 | Characteristics of 203 cases of invasive Trichosporon infection according to the underlying conditions.

\begin{tabular}{|c|c|c|c|c|c|}
\hline & \multicolumn{4}{|c|}{ Groups of patients } & \multirow[t]{2}{*}{$p$-value } \\
\hline & Hemopathies & Other immunodeficiency conditions & Newborns & Miscellaneous & \\
\hline No. of cases (\%) & 79 (39) & $41(21)$ & $25(12)$ & $58(28)$ & \\
\hline Age (Mean \pm SD) & $39.5 \pm 21.58$ & $39.3 \pm 22.2$ & $N A^{a}$ & $46.8 \pm 23.1$ & $N S^{b}$ \\
\hline Sex ratio (F/M) & $21 / 530.39$ & $14 / 230.6$ & $8 / 90.8$ & 24/34 0.7 & NS \\
\hline \multicolumn{6}{|l|}{ AT THE TIME OF DIAGNOSIS (\%) } \\
\hline Neutropenia & $67(85)$ & $3(8)$ & $0(0)$ & $0(0)$ & $<0.0001$ \\
\hline $\mathrm{CVC}^{\mathrm{C}}$ & $36(46)$ & $15(36)$ & $12(48)$ & $19(34)$ & NS \\
\hline Breakthrough infection & $59(74)$ & $12(27)$ & $2(8)$ & $9(16)$ & $<0.0001$ \\
\hline Previous antimicrobial therapy & $65(82)$ & $24(58)$ & $24(96)$ & $39(67)$ & 0.005 \\
\hline \multicolumn{6}{|l|}{ CLINICAL PRESENTATION } \\
\hline Disseminated & $79(100)$ & $25(61)$ & $25(100)$ & $33(56)$ & $<0.0001$ \\
\hline w/skin lesions & $27(34)$ & $7(28)$ & $0(0)$ & $4(12)$ & 0.001 \\
\hline w/pulmonary lesions & $33(42)$ & $6(24)$ & $1(5)$ & $3(9)$ & 0.0003 \\
\hline w/liver and/or spleen lesions & $11(14)$ & $1(4)$ & $0(0)$ & $1(3)$ & 0.06 \\
\hline Localized deep-seated infections & $0(0)$ & $16(39)$ & $0(0)$ & $25(44)$ & $<0.0001$ \\
\hline \multicolumn{6}{|l|}{ SPECIES } \\
\hline Trichosporon asahiid & $32(40)$ & $20(48)$ & $16(64)$ & $27(46)$ & NS \\
\hline Trichosporon inkine & $1(1)$ & $9(22)$ & $0(0)$ & $6(11)$ & 0.0003 \\
\hline Trichosporon mucoides/dermatis ${ }^{f, g}$ & $2(2)$ & $4(9)$ & $3(12)$ & $2(3)$ & NS \\
\hline Other Species ${ }^{h}$ & $4(5)$ & $2(5)$ & $1(4)$ & $5(10)$ & NS \\
\hline $\begin{array}{l}{ }^{a} N A, \text { Not applicable. } \\
{ }^{b} N S \text {, not statistical. } \\
{ }^{c} \text { Central venous catheter. } \\
{ }^{d} \text { Ten, six, and ten isolates had IGS1, IT } \\
{ }^{e} \text { Four, three, and three isolates had IGS } \\
{ }^{f} \text { The isolates identified as Trichosporon } \\
\text { were merged into a single group (Gunn } \\
{ }^{g} \text { Two and one isolates had IGS1 and IT } \\
{ }^{h} \text { Trichosporon asteroides ( } n=5, \text { four } \\
\text { Trichosporon mycotoxinovorans ( } n=2 \\
\text { (n } n=1 \text {, ITS1 sequence-based identifice } \\
\text { infections attributed to the obsolete T. }\end{array}$ & $\begin{array}{l}\text { d D1/D2 sequence } \\
\text { 1, and D1/D2 sequ } \\
\text { les by phenotypica } \\
\text { 2006). } \\
\text { quence-based iden } \\
\text { had IGS1 and D1/ } \\
\text { and D1/D2 seque } \\
\text { Trichosporon faeca } \\
\text { and T. cutaneum c }\end{array}$ & $\begin{array}{l}\text { identification, respectively. } \\
\text { pased identification, respectively. } \\
\text { ds, which do not distinguish T. mucoides from } \\
\text { an, respectively. } \\
\text { quence-based identification, respectively) Tric } \\
\text { sed identification), Trichosporon laibachii (n } \\
\text { :1, IGS1 sequence-based identification). To } \\
\text { ations were considered as caused by Trichosh }\end{array}$ & $\begin{array}{l}\text { matis in the abs } \\
\text { ron loubieri (n } \\
1 \text { sequence-bo } \\
\text { te the species- } \\
\text { sp. Significant }\end{array}$ & $\begin{array}{l}\text { fIGS1 sequence-ba } \\
\text { ITS1 sequence-bas } \\
\text { yentification), Trichos } \\
\text { c peculiarities, the r } \\
\text { ces are indicated in }\end{array}$ & $\begin{array}{l}\text { ntification, } \\
\text { japonicum } \\
\text { describing }\end{array}$ \\
\hline
\end{tabular}

bone marrow or a blood cord transplant, four (50\%) during the pre-engraftment period and under antifungal prophylaxis [(amphotericin B (AMB) $n=2$, caspofungin $n=1$, voriconazole $n=1)$ ], four $(50 \%)$ after severe graft-vs.-host disease and under AMB prophylaxis. Thirty-six patients $(45.5 \%)$ had at least one central venous catheter (CVC) when the diagnosis of ITI was established. All the cases corresponded to a disseminated infection, 29 (36.7\%) being isolated fungemia. Organ involvement occurred in 50 patients (63.2\%). In these cases, pulmonary infection was the most common $(n=33$; $41.7 \%$ ), followed by skin lesions, which were observed in 27 cases (34.1\%). On the whole group, an antimicrobial therapy regimen prior to the episode of ITI was mentioned in 65 cases $(82.2 \%)$. Fifty-nine patients $(74.6 \%)$ had breakthrough Trichosporon infection during treatment with different antifungal drugs, including an echinocandin $(n=16)$, AMB $(n=25)$ or azole derivatives $(n=18)$.

\section{Other Immunodeficiency Disorders $(n=41)$}

In this group, trichosporonosis mainly occurred in patients with solid organ transplantation $(n=13)$, solid tumors $(n=$
11) or autoimmune diseases $(n=8)$. Kidney transplantation $(n=6)$ and lung cancer $(n=4)$ were the main underlying conditions within the two predominant groups. A disseminated infection was diagnosed in 25 cases (60.9\%) and deep-organ involvement was noticed in 12 cases (48\%); skin and pulmonary lesions being noticed in 7 and 6 cases, respectively. Isolated pneumonia was diagnosed in three cases, and another three cases had chronic lung infections presenting with pulmonary abscesses or a penetrating chest wall mass. Twenty-four (58.5\%), $14(34.1 \%)$, and $13(31.7 \%)$ patients had received antimicrobials, corticosteroids, and immunosuppressive drugs, respectively, before the diagnosis of the invasive fungal infection. Breakthrough infections were documented in 12 cases (29.2\%).

\section{Other Clinical Contexts $(n=58)$}

Finally, we found 58 cases of ITI in patients with miscellaneous underlying conditions. Forty of them (68.9\%) had received antimicrobial therapy before the diagnosis of deed-seated trichosporonosis. Among the 33 patients (56.8\%) with disseminated disease, 31 (93.9\%) had severe baseline disease [(heart failure or pulmonary embolism $(n=8 ; 24.2 \%)$, extensive 
burns $(n=5 ; 15.1 \%)$, polytrauma $(n=4 ; 12.1 \%)]$ and were in intensive care units; $20(60 \%)$ of them were reported to have a CVC at the time of the infection. Additionally, four (12.1\%) had multiple surgeries before developing disseminated trichosporonosis and another four patients developed disseminated trichosporonosis during hemodialysis (12.1\%). Moreover, breakthrough infections occurred in nine patients that had disseminated infection $(27.2 \%)$.

Fourteen patients $(24.1 \%)$ were diagnosed with deepseated post-operative infections, notably endocarditis after valve replacement surgery $(n=5)$. Interestingly, the time between the surgery and the occurrence of endocarditis was quite long, ranging from 3 months to 8 years (median 3 years).

Twelve cases of Trichosporon peritonitis were recorded, and $11(91.6 \%)$ of those cases complicated the course of continuous ambulatory peritoneal dialysis.

\section{Newborns $(n=25)$}

Twenty-five cases of ITI occurred in newborns. It is worth noting that eleven cases were reported in two outbreaks from Indian hospitals (Vashishtha et al., 2012; Basu et al., 2015). Infections occurred between the third and the 84th day of life. All of the infants except two were preterm at delivery, and 10 (40\%) had extremely low birth weight $(<1000 \mathrm{~g})$. A previous diagnosis of perinatal asphyxia or respiratory distress syndrome was identified in 15 cases (60\%), and all of the newborns but one received previous antimicrobial therapy. Trichosporon infection was disseminated in all cases either as isolated fungemia $(n=$ $22 ; 88 \%)$ or associated with a deep-organ involvement $(n=3$; $12 \%)$. Twelve infants (48\%) had a CVC at the time of diagnosis of the ITI.

\section{Diagnostic Procedures}

The diagnosis of ITI relied in all the cases on a positive culture for Trichosporon from a clinical sample. In the 47 cases with a pathological examination of biopsy specimens, the presence of arthroconidia was only mentioned in eight cases (17\%). Positive blood culture(s), as unique fungal isolation, was the most common presentation ( $n=100 ; 49.2 \%)$. In 69 cases $(33.9 \%)$, there was no identification at the species level. Species identification relied on molecular analysis of intergenic spacer IGS1 $(n=22)$, ITS1 $(n=15)$ or D1/D2 domain of the $26 \mathrm{~S}$ regions of the rRNA gene $(n=15)$ (Table 2$)$. In other cases, there was either no information regarding the method used for identification or the isolates were identified using a commercial phenotypic method. Overall, Trichosporon asahii $(n=95 ; 46.7 \%)$ was the main etiologic agent. Nine additional species were identified: Trichosporon inkin $(n=16)$, Trichosporon dermatis/mucoides $(n=11)$, and Trichosporon spp. $(n=12)$. T. inkin was significantly less prevalent in patients with homeopathy than in the rest of the population analyzed ( $p=$ 0.0003).

A positive serum Cryptococcus glucuronoxylomannan (GXM) antigen assay was reported in 4 of 15 cases $(26.6 \%)$ while $\beta$-Dglucan (BDG) was detected in the serum of 9 among 11 tested patients $(81.8 \%)$.

\section{Treatment and Outcome}

Twenty-five different antifungal regimens were reported. AMB was used in 111 cases, mainly as deoxycholate AMB $(n=$ $89)$ and liposomal AMB $(n=18)$. Thirteen patients received targeted treatment with echinocandins either in monotherapy $(n=5)$ or combined with other antifungal $(n=8)$. All those patients treated with echinocandin monotherapy for disseminated infection died. Fluconazole was the azole drug the most frequently used for the treatment of those infections ( $n$ $=54$ ). Combined antifungal therapy was commonly used ( $n$ $=48 ; 24.2 \%)$. Twelve patients did not receive any antifungal treatment, and 11 died. The unfavorable outcome rate was calculated at $44.3 \%$. Table 2 summarizes the impact of various prognosis factors. In the univariate analysis, advanced age, disseminated infection and neutropenia at the time of diagnosis were associated with unfavorable outcome $(p<0.05)$. There was also a similar trend for breakthrough infection and curative therapy including an echinocandin drug $(p<0.1)$. By the contrary, patients from group 2 and 3 , and the use of either azole or voriconazole in the therapeutic management were associated with a better outcome. In the multivariate analysis, breakthrough infection and azole-based therapy remained significant $(p<$ $0.05)$ with odds ratio (IC95\%) at $2.45(1.05-5.97)$ and 0.17 (0.060-0.423), respectively. In neutropenic patients, we also found the recovery of a normal neutrophils count as a favorable prognosis factor with mortality rate at 15 vs. $92.31 \%(p=$ 0.001). Finally, in patients with hematologic disease, the use of voriconazole in the curative regimen led to a significantly better prognosis: favorable outcome rate at 73.6 vs. $41.8 \%$ ( $p=$ $0.016)$.

\section{Antifungal Susceptibility Testing (AST)}

Details from 19 studies having tested at least 10 Trichosporon clinical isolates for a given species with a microdilution method are presented in Tables 3-8 (Arikan and Hasçelik, 2002; Paphitou et al., 2002; Ramos et al., 2004; Metin et al., 2005; RodriguezTudela et al., 2005; de Oliveira Silva et al., 2008; Chagas-Neto et al., 2009; Taj-Aldeen et al., 2009; Thompson et al., 2009; Lemes et al., 2010; Mekha et al., 2010; Guo et al., 2011; Sun et al., 2012; Tsai et al., 2012; Hazirolan et al., 2013; Yang et al., 2013; Arabatzis et al., 2014; Taverna et al., 2014; Montoya et al., 2015). Up to now, there is no recommendation from the two main consortia (EUCAST and CLSI) regarding the AST of Trichosporon. Thus, it is important to note that the analyzed studies included some variants in the application of the EUCAST or CLSI method: three studies applied the EUCAST methodology including agitation at $350 \mathrm{rpm}$ during incubation (Rodriguez-Tudela et al., 2005; de Oliveira Silva et al., 2008; Taverna et al., 2014), and one of them incubated the plates at $30^{\circ} \mathrm{C}$ (Rodriguez-Tudela et al., 2005). Two studies analyzed the CLSI method with MIC determination by spectrophotometric reading (Taj-Aldeen et al., 2009; Tsai et al., 2012). Interestingly, some works included comparisons of either culture media (Tsai et al., 2012) or incubation times (24 vs. 48 h; Arikan and Hasçelik, 2002; Metin et al., 2005; Chagas-Neto et al., 2009; Lemes et al., 2010; Tsai et al., 2012; Hazirolan et al., 2013). 
TABLE 2 | Outcome predictors in patients with invasive Trichosporon infection according to univariate and multivariate analysis.

\begin{tabular}{|c|c|c|c|c|c|}
\hline & No. of patients & Unfavorable outcome rate (\%) & \multicolumn{2}{|c|}{$p$-value } & Odds Ratio $(95 \% \mathrm{Cl})$ \\
\hline Female & 66 & 42.42 & & & \\
\hline Male & 120 & 45.83 & & & \\
\hline Underlying disease ${ }^{a}$ & & & & NS & \\
\hline 1 & 79 & 53.16 & & NS & \\
\hline 2 & 41 & 36.59 & $0.087^{a}$ & & \\
\hline 3 & 58 & 34.48 & $0.031^{a}$ & & \\
\hline 4 & 25 & 52.00 & NS & & \\
\hline 3 & 11 & 18.18 & $0.084^{a}$ & & \\
\hline 4 & 81 & 46.91 & NS & & \\
\hline Breakthrough infection & & & 0.053 & 0.049 & $2.45(1.05-5.97)$ \\
\hline Yes & 84 & 52.38 & & & \\
\hline No & 119 & 38.66 & & & \\
\hline Disseminated infection & & & 0.001 & 0.070 & $2.62(0.92-7.45)$ \\
\hline Yes & 162 & 50.62 & & & \\
\hline No & 41 & 19.51 & & & \\
\hline
\end{tabular}

Coinfection

$\begin{array}{lcc}\text { Yes } & 19 & 47.37 \\ \text { No } & 184 & 44.02\end{array}$

\section{Antifungal therapy}

Amphotericin-based

$\begin{array}{ccc}\text { Yes } & 112 & 49.11 \\ \text { No } & 91 & 38.46\end{array}$

Echinocandin-based

$\begin{array}{lrr}\text { Yes } & 13 & 69.23 \\ \text { No } & 190 & 42.63\end{array}$

NS

44.02

\begin{tabular}{|c|c|c|c|c|c|}
\hline Azole based & & & $<0.001$ & $<0.001$ & $0.15(0.06-0.42)^{b}$ \\
\hline Yes & 101 & 28.71 & & & \\
\hline No & 102 & 67.78 & & & \\
\hline Voriconazole based & & & 0.035 & NS & \\
\hline Yes & 33 & 27.27 & & & \\
\hline No & 170 & 47.65 & & & \\
\hline
\end{tabular}

${ }^{a}$ Comparison to the reference i.e., Trichosporon asahii for species and hematological patients for group of patients, respectively.

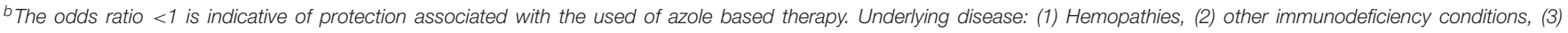
miscellaneous diseases, (4) neonates. Species: (1) Trichosporon asahii, (2) Trichosporon inkin, (3) Trichosporon dermatis/mucoides, (4) Trichosporon beigelii and other species. 
TABLE 3 | In vitro susceptibility testing of amphotericin B against Trichosporon asahii clinical isolates.

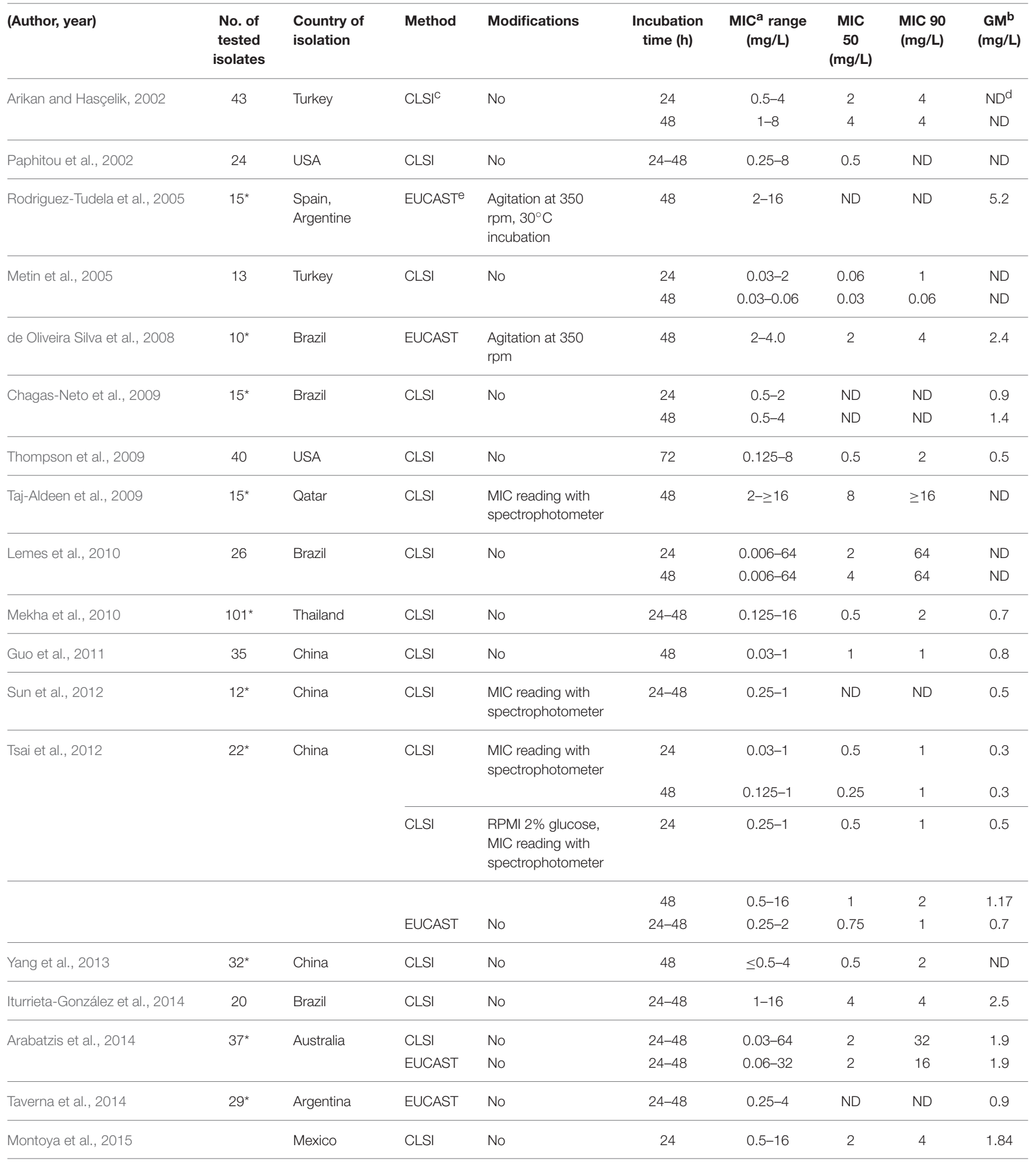

${ }^{a}$ MIC, minimal inhibitory concentration.

${ }^{b} G M$, Geometric mean.

${ }^{c} C L S I$, Clinical Laboratory Standards Institute.

${ }^{d} N D$, not described.

${ }^{e}$ EUCAST, European Committee on Antimicrobial Susceptibility Testing.

*Studies having confirmed species identification using molecular analysis. 
TABLE 4 | In vitro susceptibility testing of fluconazole against Trichosporon asahii clinical isolates.

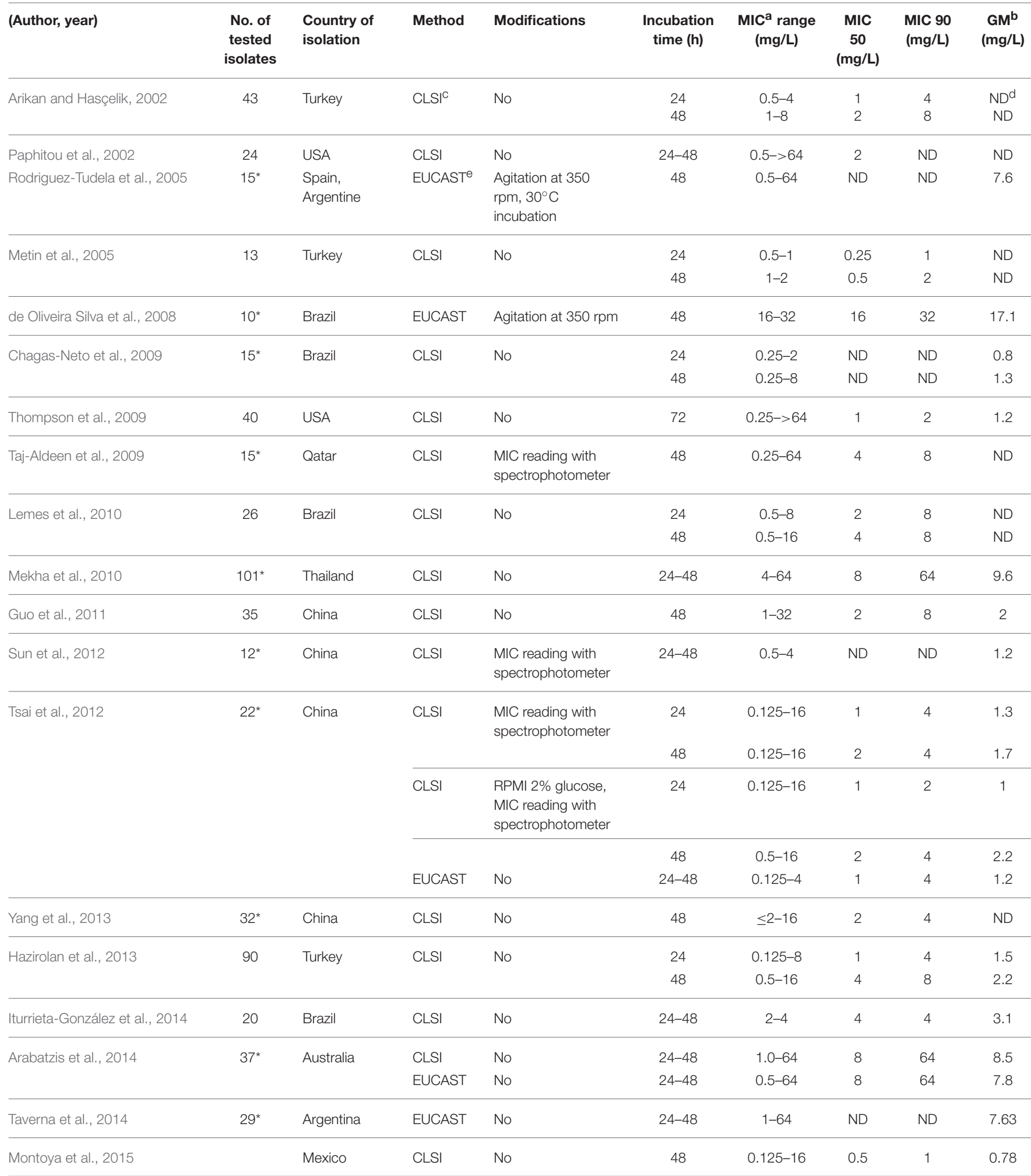

${ }^{a}$ MIC, minimal inhibitory concentration.

${ }^{b} \mathrm{GM}$, Geometric mean.

${ }^{c} C L S I$, Clinical Laboratory Standards Institute.

${ }^{d} N D$, not described.

${ }^{\circledR}$ EUCAST, European Committee on Antimicrobial Susceptibility Testing.

${ }^{*}$ Studies having confirmed species identification using molecular analysis. 
TABLE 5 | In vitro susceptibility testing of voriconazole against Trichosporon asahii clinical isolates.

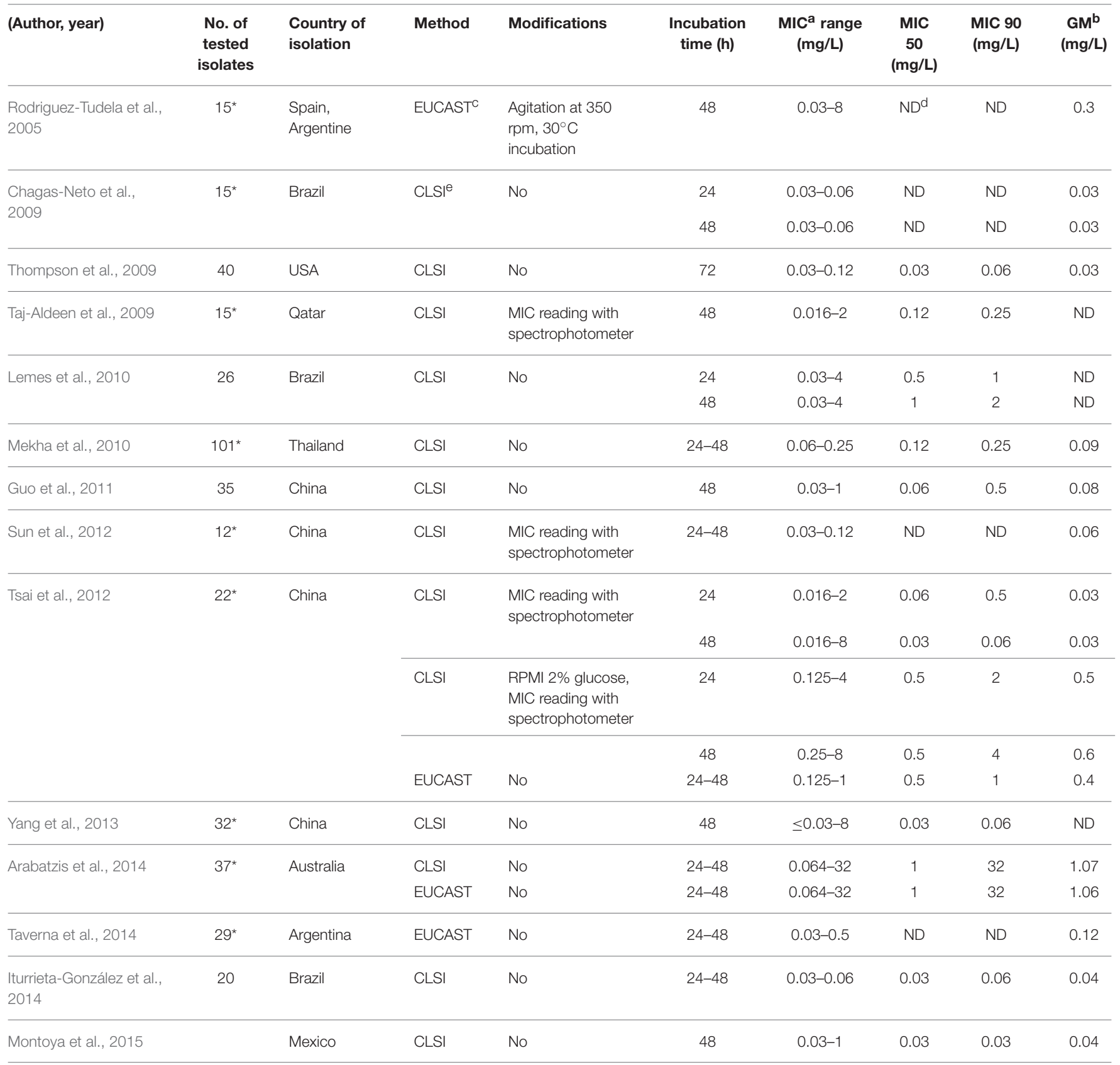

${ }^{a} M I C$, minimal inhibitory concentration.

${ }^{b} \mathrm{GM}$, Geometric mean.

${ }^{c}$ EUCAST, European Committee on Antimicrobial Susceptibility Testing.

${ }^{d} N D$, not described.

${ }^{e}$ CLSI, Clinical Laboratory Standards Institute.

*Studies having confirmed species identification using molecular analysis.

\section{AST of Trichosporon asahii Isolates}

By far, T. asahii was the most studied species (636 isolates evaluated amongst 698). The distribution of minimal inhibitory concentrations (MICs) against $\mathrm{AMB}$ was quite heterogeneous (Table 3), with $\mathrm{MIC}_{50}$ s (concentration that inhibits the growth of $50 \%$ of the tested isolates), $\mathrm{MIC}_{90} \mathrm{~s}$ (concentration that inhibits the growth of $90 \%$ of the tested isolates) and MIC geometric means (GMs) ranging between $0.03-8,1-64$, and $0.26-5.2 \mathrm{mg} / \mathrm{L}$, respectively. Higher MIC values for $\mathrm{AMB}$ were described notably in two studies that applied the EUCAST methodology with agitation during incubation (isolates from Spain, Argentina, and Brazil; Rodriguez-Tudela et al., 2005; de Oliveira Silva et al., 2008). 
TABLE 6 | In vitro susceptibility testing of posaconazole and isavuconazole against Trichosporon asahii clinical isolates.

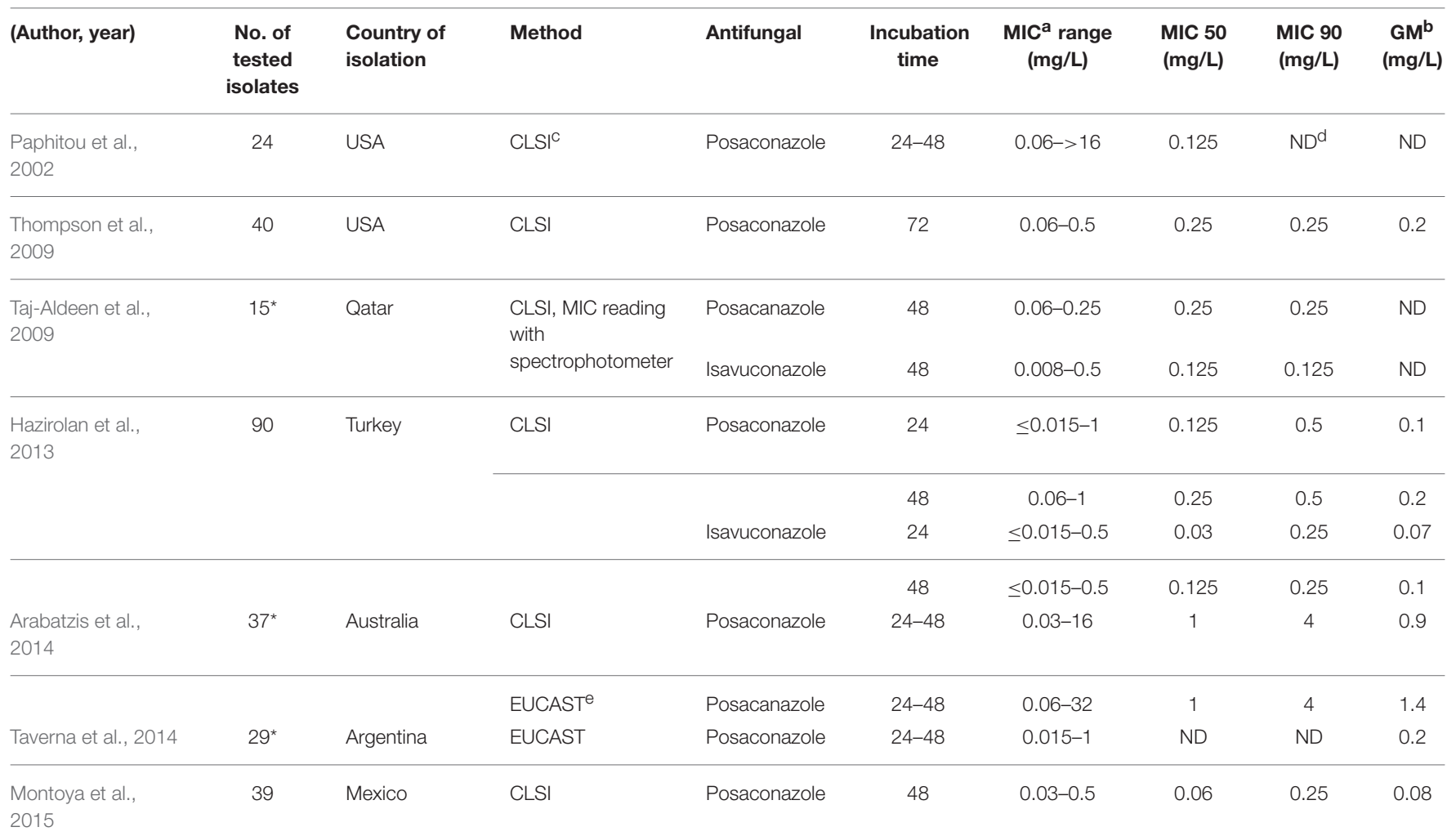

${ }^{a} M I C$, minimal inhibitory concentration.

${ }^{b} G M$, Geometric mean.

${ }^{c}$ CLSI, Clinical Laboratory Standards Institute.

${ }^{d} N D$, not described.

EEUCAST, European Committee on Antimicrobial Susceptibility Testing.

*Studies having confirmed species identification using molecular analysis.

TABLE 7 | In vitro susceptibility testing against Trichosporon inkin clinical isolates.

\begin{tabular}{|c|c|c|c|c|c|c|c|c|c|}
\hline (Author, year) & $\begin{array}{l}\text { No. of tested } \\
\text { isolates }\end{array}$ & $\begin{array}{l}\text { Country of } \\
\text { isolation }\end{array}$ & Method & $\begin{array}{l}\text { Incubation } \\
\text { time (h) }\end{array}$ & Antifungal & $\begin{array}{l}\mathrm{MIC}^{\mathrm{a}} \text { range } \\
\text { (mg/L) }\end{array}$ & $\begin{array}{l}\text { MIC } 50 \\
\text { (mg/L) }\end{array}$ & $\begin{array}{l}\text { MIC } 90 \\
\text { (mg/L) }\end{array}$ & $\begin{array}{l}\mathrm{GM}^{\mathrm{b}} \\
(\mathrm{mg} / \mathrm{L})\end{array}$ \\
\hline \multirow[t]{3}{*}{ Ramos et al., 2004} & 11 & Spain & $\begin{array}{l}\text { EUCAST }^{\mathrm{C}} \text {, Agitation at } \\
350 \mathrm{rpm}, 30^{\circ} \mathrm{C} \\
\text { incubation }\end{array}$ & 48 & $\mathrm{AMB}^{\mathrm{d}}$ & $0.006-1$ & 0.25 & 1 & 0.3 \\
\hline & & & & & Fluconazole & $1.0-32$ & 2 & 8 & 2.7 \\
\hline & & & & & Voriconazole & $0.03-0.5$ & 0.12 & 0.5 & 0.11 \\
\hline \multirow{2}{*}{$\begin{array}{l}\text { Rodriguez-Tudela } \\
\text { et al., } 2005\end{array}$} & & & & & Fluconazole & $0.5-4$ & ND & ND & 2 \\
\hline & & & & & Voriconazole & $0.03-2$ & ND & ND & 0.12 \\
\hline
\end{tabular}

${ }^{a}$ MIC, minimal inhibitory concentration.

${ }^{b} \mathrm{GM}$, Geometric mean.

${ }^{c}$ EUCAST $=$ European Committee on Antimicrobial Susceptibility Testing.

${ }^{d} A M B$, amphotericin $B$.

*Studies having confirmed species identification using molecular analysis.

Among the azole compounds, fluconazole was the compound most extensively analyzed (Table 4). MIC distribution of fluconazole was also heterogeneous, with $\mathrm{MIC}_{50} \mathrm{~s}, \mathrm{MIC}_{90} \mathrm{~s}$ and
MIC geometric means (GMs) ranging between 0.5-16, 1-64, and $0.8-17.1 \mathrm{mg} / \mathrm{L}$, respectively. Again, higher MIC values were described notably in three studies that applied the EUCAST 
TABLE 8 | In vitro susceptibility testing against Trichosporon mucoides/dermatis clinical isolates.

\begin{tabular}{|c|c|c|c|c|c|c|c|c|c|}
\hline (Author, year) & $\begin{array}{l}\text { No. of tested } \\
\text { isolates }\end{array}$ & $\begin{array}{l}\text { Country of } \\
\text { isolation }\end{array}$ & Method & Antifungal & $\begin{array}{l}\text { Incubation } \\
\text { time (h) }\end{array}$ & $\begin{array}{l}\mathrm{MIC}^{\mathrm{a}} \\
\text { range } \\
\text { (mg/L) }\end{array}$ & $\begin{array}{l}\text { MIC } 50 \\
(\mathrm{mg} / \mathrm{L})\end{array}$ & $\begin{array}{c}\text { MIC } 90 \\
(\mathrm{mg} / \mathrm{L})\end{array}$ & $\begin{array}{c}\mathrm{GM}^{\mathrm{b}} \\
(\mathrm{mg} / \mathrm{L})\end{array}$ \\
\hline \multirow[t]{3}{*}{$\begin{array}{l}\text { Rodriguez- } \\
\text { Tudela et al., } \\
2005\end{array}$} & $16^{\star}$ & $\begin{array}{l}\text { Spain, } \\
\text { Argentine }\end{array}$ & $\begin{array}{l}\text { EUCASTC }^{\mathrm{C}} \text {, Agitation at } \\
350 \mathrm{rpm}, 30^{\circ} \mathrm{C} \\
\text { incubation }\end{array}$ & $\mathrm{AMB}^{\mathrm{d}}$ & 48 & $0.03-1$ & ND & ND & 0.2 \\
\hline & & & & Fluconazole & 48 & $0.5-4$ & ND & ND & 2 \\
\hline & & & & Voriconazole & 48 & $0.03-2$ & ND & ND & 0.12 \\
\hline \multirow{6}{*}{$\begin{array}{l}\text { Metin et al., } \\
2005\end{array}$} & 14 & Turkey & $\mathrm{CLSI}^{\mathrm{e}}$ & AMB & 24 & $0.03-4$ & 0.03 & 0.25 & ND \\
\hline & & & & & 48 & $0.03-4$ & 0.06 & 2 & ND \\
\hline & & & & Fluconazole & 24 & $0.125-32$ & 1 & 2 & ND \\
\hline & & & & & 48 & $0.125-64$ & 2 & 8 & ND \\
\hline & & & & Voriconazole & 24 & $0.03-0.5$ & 0.03 & 0.03 & ND \\
\hline & & & & & 48 & $0.3-0.5$ & 0.03 & 0.25 & ND \\
\hline \multirow{3}{*}{$\begin{array}{l}\text { Thompson et al., } \\
2009\end{array}$} & 10 & USA & CLSI & AMB & 72 & $0.125-8$ & 0.5 & 2 & 0.5 \\
\hline & & & & Fluconazole & 72 & $0.12-1$ & 0.12 & 1 & 0.25 \\
\hline & & & & Voriconazole & 72 & $0.03-0.06$ & 0.03 & 0.06 & 0.03 \\
\hline
\end{tabular}

${ }^{a}$ MIC, minimal inhibitory concentration.

${ }^{b} \mathrm{GM}$, Geometric mean.

${ }^{c}$ EUCAST, European Committee on Antimicrobial Susceptibility Testing.

${ }^{d} A M B$, amphotericin $B$.

${ }^{e}$ CLSI, Clinical and Laboratory Standards Institute.

*Studies having confirmed species identification using molecular analysis.

methodology with agitation during incubation (isolates from Spain, Argentina, and Brazil; Rodriguez-Tudela et al., 2005; de Oliveira Silva et al., 2008; Taverna et al., 2014). Lowest MICs were observed for the last generation of triazoles, i.e., voriconazole (Table 5), and indeed for isavuconazole and posaconazole (Table 6).

Interestingly, while individual studies did not find any correlation between genotype and in vitro susceptibility, when merging the data available from 4 well-designed studies (Rodriguez-Tudela et al., 2007; Guo et al., 2011; Yang et al., 2013; Arabatzis et al., 2014), we noted that genotype 3 strains may exhibit higher MICs to voriconazole than genotype 1 strains: MIC GM 0.12 vs. $0.49 \mathrm{mg} / \mathrm{L}, p=0.04$, whereas the MIC values of $\mathrm{AMB}$ (MIC GM 1.9 vs. 1.2, $p=0.2$ ) and fluconazole (MIC GM 5.2 vs. $5.6, p=0.7)$ were similar for both genotypes.

Of note, the reading at $48 \mathrm{~h}$ instead of $24 \mathrm{~h}$ only slightly increases the MICS by one dilution and the results obtained either using the CLSI or the EUCAST method are quite similar with the possible exception of voriconazole for which higher MICs were observed using the EUCAST method in one of two studies (Tsai et al., 2012; Arabatzis et al., 2014).

\section{AST of Trichosporon inkin, Trichosporon Mucoides/Dermatis Isolates}

In comparison to T. asahii, a much narrow MICs distribution for $\mathrm{AMB}$ was described for both species, with MIC GM ranging between $0.21-0.29 \mathrm{mg} / \mathrm{L}$ for $T$. inkin (Table 7) and $0.61-0.69$ $\mathrm{mg} / \mathrm{L}$ for $T$. mucoides/dermatis (Table 8). Conversely, a wide range of MIC GMs of fluconazole against T. mucoides/dermatis has been reported, ranging from 0.25 to $7 \mathrm{mg} / \mathrm{L}$. Two of three studies described higher fluconazole MICs of $T$. mucoides/dermatis isolates in comparison to the MICs of $T$. asahii isolates (Metin et al., 2005; Rodriguez-Tudela et al., 2005). The MIC GM of fluconazole against T. inkin isolates ranged from 2 to $2.74 \mathrm{mg} / \mathrm{L}$. Rodriguez-Tudella and collaborators described lower MICs of fluconazole against T. inkin isolates in comparison to T. asahii and T. mucoides/dermatis isolates (Rodriguez-Tudela et al., 2005). Voriconazole exhibited the lowest MICs against both T. inkin and T. mucoides/dermatis, with MIC GMs ranging from 0.11 to 0.12 for T. inkin and 0.03 to 0.25 for T. mucoides/dermatis.

\section{DISCUSSION}

Trichosporon emerged as a pathogen in the 70-80's, mainly for neutropenic patients (Gold et al., 1981; Walsh et al., 1986). Despite the lack of data providing the real incidence of ITI at this time, published series supported the fact that Trichosporon was the second most frequent agent responsible for fungemia in this population (Leblond et al., 1986; Anaissie et al., 1992). Based on clinical and experimental data, it was then shown that azoles had a significant activity against Trichosporon, while being less toxic that the standard at that time treatment, 
amphotericin B (Anaissie et al., 1992). This and the wider use of azole drugs either as prophylaxis or empirical therapy probably explain the decreasing concern regarding ITI in 90's. Between 1989 and 2002, an estimated incidence, of 81 cases per 100,000 admissions and 3 per 100,000 admissions were reported in patients with hematologic malignancies and patients with solid tumors, respectively (Kontoyiannis et al., 2004). Similarly, in an Italian multicentric study conducted in 15 hematology departments between 1983 and 2002, an incidence of $0.4 \%$ was observed in patients with acute leukemia (Girmenia et al., 2005). However, more recently, the MD Anderson Cancer Center (TX, USA) demonstrated an increase in the incidence of invasive yeast infections not due to Candida or Cryptococcus, of which $20 \%$ were Trichosporon, from 1.8 to 2.35 cases per 100,000 patient-days between the periods 1998-2004 and 2005-2010 (Chitasombat et al., 2012). Again this may reflect the change in the antifungal stewardship for neutropenic patients. Indeed, echinocandin drugs, which emerged as valuable options of choice for either prophylaxis, pre-emptive or empirical therapy, have no effect on Trichosporon (Asada et al., 2006; Matsue et al., 2006; Hiramatsu et al., 2008; Suzuki et al., 2010; Park et al., 2014; Nachbaur et al., 2015). Our review supports this re-emergence with a significant increase of reported cases in the second part of the 2000 s decade.

In accordance with previous studies, we found that hematological diseases (38.9\% of the cases), mainly acute leukemia, remain the most common underlying condition of ITI, however, with a much smaller percentage than previous reported (Girmenia et al., 2005). Eighty-five percent of the patients with hematological diseases were neutropenic at the time of ITI diagnosis, supporting the fact that neutrophil cells are, as for candidiasis and aspergillosis, essential in the prevention of ITI. The disruption of the mucosal barrier owing to chemotherapy-induced mucositis may also contribute to invasion of the yeast cells. This, combined with the modification of the digestive flora due to previous antibiotic therapies, observed in 58-96\% of the cases according to the patients' group, may favor the translocation of yeasts from the digestive tract to the blood vessels. However, our study also revealed that not only patients with hematological malignancy are now concerned, as we showed that other conditions mainly related to severe baseline diseases (e.g., SOT, auto-immune diseases, solid tumor, preterm birth, extensive skin lesions such as burns, or pemphigus) and invasive procedures (e.g., CVC, prosthetic heart valves), may also favor the occurrence of ITI.

The origin of Trichosporon infections, notably post-operative ones, is uncertain. Indeed, Trichosporon has been isolated from the hospital environment (Fanfair et al., 2013), but is also considered a commensal of the digestive tract and may colonize the skin of healthy patients (Colombo et al., 2011; Zhang et al., 2011; Cho et al., 2015). In neonates, it is likely that the increasing permissiveness of the natural barriers, mainly the skin and the digestive mucosa, may favor the translocation of any yeast types, including Trichosporon, which has also been isolated from the skin of preterm infants (Kaufman et al., 2001). In addition, total parenteral nutrition, frequently used in this context, may have been the source of an outbreak of T. asahii bloodstream infections (Vashishtha et al., 2012).

In any case, the clinical features of invasive trichosporonosis were not specific. The persistence of fever during ongoing treatment with $\mathrm{AMB}$ or echinocandins may be more supportive (Colombo et al., 2011). Dissemination is a common feature, particularly in patients with homeopathy and newborns $(100 \%$ of the cases). While difficult to interpret when solely based on culture results, pulmonary lesions are frequently reported as diffuse nodules, lobar pneumonia, reticulonodular infiltrates, or mass-like lesions (Akagi et al., 2006; Kendirli et al., 2006). Positive culture for Trichosporon from respiratory tract samples, notably when repeated should always be interpreted with caution in patients with risk factors. Skin lesions were the second most common tissue involvement and warrant the addition of trichosporonosis to the list, which included candidiasis and fusariosis, as a cause of skin lesions during febrile neutropenia. The cutaneous lesions, mainly located in the lower extremities, the trunk and the face, are typically hemorrhagic macular or maculopapular, and differ in subtle way from those of Candida that tend to be punctate, pseudopustular (necrotic epicenter) with a rim of erythema (Nucci et al., 1992; Higgins et al., 1994; Miura et al., 2007).

The diagnosis of ITI always relies on the isolation of a yeastlike organism from a clinical specimen further identified as Trichosporon. Direct examination of clinical specimens rarely contributed to diagnosis as it rarely demonstrated arthroconidia in samples. It is remarkable than about a third of the isolates had not been identified at the species level. Phenotypic approaches have been shown to be poorly efficient and direct sequencing of the IGS1 region of the ribosomal DNA is now considered the reference method for species identification of Trichosporon isolates (Sugita et al., 2002). MALDI-TOF mass spectrometry, which has recently been shown to be a valuable alternative for routine identification (de Almeida Júnior et al., 2014), should help at reducing the part of non- or uncertainlyidentified isolates in order to test more in depth, possible speciesspecific epidemiological traits, and clinical scenarios. Therapeutic adaptation may also be required according to the causative species.

Unfortunately, serum markers are either unsatisfactory or have not been evaluated in depth for the diagnosis of ITI. Although, it is well-known that Trichosporon shares some antigenic properties with Cryptococcus neoformans (Campbell et al., 1985), a cross reaction with the cryptococcal GXM antigen assay was only found in $26 \%$ of the tested cases; a negative assay thus does not rule out the diagnosis. BGD assays may be more interesting with nine positive results among 11 sera tested. Similarly, in a case series study, 12 out of 25 patients with Trichosporon fungemia have been reported with significant levels of BDG (Suzuki et al., 2010). While the use of molecular tools, not commercially available, is more anecdotal, a study reported a good performance of a real-time PCR assay to detect T. asahii DNA from the blood samples (Tsuji et al., 2008).

T. asahii was shown to be associated with a poor prognosis what may be due in part to its lower susceptibility to antifungal drugs (Pfaller et al., 2009). Nevertheless, neither the CLSI 
nor the EUCAST consortium has proposed a standardized procedure for AST of Trichosporon. Zaragoza et al. analyzed different parameters for optimal growth of nonfermentative yeasts, including some Trichosporon strains, for AST (Zaragoza et al., 2011), and showed that the use of yeast nitrogen base medium (YNB), agitation and incubation at $30^{\circ} \mathrm{C}$ resulted in a better growth and a more reliable and stable measurement of the MIC values. However, whatever was the conditions used they found an excellent agreement between the methods when reading the MICs after $48 \mathrm{~h}$ of incubation (Zaragoza et al., 2011).

Despite the lack of defined clinical breakpoints, the constantly elevated MICs against the echinocandins support natural resistance to this antifungal class (Colombo et al., 2011). Similarly, because the minimal fungicidal concentrations of polyenes have been shown to be 20 -fold greater than the minimal inhibitory concentration, the Trichosporon genus was also considered naturally resistant to these drugs, notably AMB (Walsh et al., 1990). However, after the taxonomic reevaluation, it has been shown that T. asahii clearly exhibits higher MICs against AMB compared to other species, such as T. mucoides/dermatis and T. inkin (Rodriguez-Tudela et al., 2005; Tsai et al., 2012). On the contrary, T. mucoides/dermatis appears to be more resistant in vitro to fluconazole compared to other species (Metin et al., 2005; Rodriguez-Tudela et al., 2005). Nevertheless, whatever is the species considered, voriconazole, posaconazole, and isavuconazole offer a better in vitro efficacy compared to fluconazole, even if some T. asahii isolates belonging to genotype 3 with reduced susceptibility to voriconazole has been described (Yang et al., 2013; Arabatzis et al., 2014). The heterogeneity of population structure of $T$. asahii may also explain the great variability in MICs found in this species against the different antifungals evaluated.

To the best of our knowledge, there is no study designed specifically to compare different antifungal regimens in the management of those infections. The lack of antifungal treatment led to a fatal outcome almost constantly. In our review, the overall unfavorable outcome rate was at $44.3 \%$. This rate was quite similar to that reported in a US Cancer Center (50\%) but slightly lower than that found in the study by Girmenia et al. (64.7\%), where AMB was the main $(76.5 \%)$ drug used for treatment. Indeed, our review suggests that azole-based therapy may be superior to echinocandin- or

\section{REFERENCES}

Abdala, E., Lopes, R. I., Chaves, C. N., Heins-Vaccari, E. M., and Shikanai-Yasuda, M. A. (2005). Trichosporon asahii fatal infection in a non-neutropenic patient after orthotopic liver transplantation. Transpl. Infect. Dis. 7, 162-165. doi: 10.1111/j.1399-3062.2005.00104.x

Abliz, P., Fukushima, K., Takizawa, K., Yang, R., Li, R., and Nishimura, K. (2002). Identification of the first isolates of Trichosporon asahii var asahii from disseminated trichosporonosis in China. Diagn. Microbiol. Infect. Dis. 44, 17-22. doi: 10.1016/S0732-8893(02)00425-X

Akagi, T., Yamaguti, K., Kawamura, T., Nakumura, T., Kubo, K., and Takemori, H. (2006). Breakthrough trichosporonosis in patients with acute myeloid leukemia receiving micafungin. Leuk. Lymphoma 47, 1182-1183. doi: $10.1080 / 10428190500272499$ amphotericin-based therapies. Similar findings were reported in a retrospective study of 33 patients with hematological malignancy: the mortality rate was $63 \%$ with azole-based therapy vs. $100 \%$ in the absence of any azole drug in the therapeutic regimen ( $p=0.031$; Suzuki et al., 2010). In our study, the use of voriconazole significantly improved the prognosis of patients with hematological malignancy supporting the recent recommendations proposed by the ESCMID (Arendrup et al., 2014).

\section{CONCLUSIONS}

Although, hematologic malignancies are the main underlying diseases, invasive Trichosporon infection may also occur in other contexts of immunosuppression, in newborns and in various conditions of debilitating diseases, with different clinical presentations. Due to the natural resistance to echinocandins and polyenes of Trichosporon, breakthrough infections are common. Bloodstream infection sometimes combined with pneumonia and/or skin lesions are the most common clinical feature in patients with hematologic malignancies. T. asahii is the predominant causative species and is associated with a poor prognosis, possibly linked to its reduce sensitivity to some azole drugs. Nevertheless, first line therapy should rely on azole derivatives and particularly voriconazole, which exhibits the best in vitro activity against Trichosporon species and significantly leads to a better outcome in patients with underlying homeopathy.

\section{AUTHOR CONTRIBUTIONS}

JN: designed the study, helped with acquisition and data analysis, drafted and revised the work, approved the final work and agrees with all the aspects of the work; $\mathrm{CH}$ : designed the study, helped with data analysis, drafted and revised the work, approved the final work, and agree with all the aspects of the work.

\section{SUPPLEMENTARY MATERIAL}

The Supplementary Material for this article can be found online at: http://journal.frontiersin.org/article/10.3389/fmicb. 2016.01629
Almeida Júnior, J. N., Song, A. T. W., Campos, S. V., Strabelli, T. M. V., Del Negro, G. M., Figueiredo, D. S. Y., et al. (2014). Invasive Trichosporon infection in solid organ transplant patients: a report of two cases identified using IGS1 ribosomal DNA sequencing and a review of the literature. Transpl. Infect. Dis. 16, 135-140. doi: 10.1111/tid.12179

Anaissie, E., Gokaslan, A., Hachem, R., Rubin, R., Griffin, G., Robinson, R., et al. (1992). Azole therapy for trichosporonosis: clinical evaluation of eight patients, experimental therapy for murine infection, and review. Clin. Infect. Dis. 15, 781-787. doi: 10.1093/clind/15.5.781

Antachopoulos, C., Papakonstantinou, E., Dotis, J., Bibashi, E., Tamiolaki, M., Koliouskas, D., et al. (2005). Fungemia due to Trichosporon asahii in a neutropenic child refractory to amphotericin B: clearance with voriconazole. J. Pediatr. Hematol. Oncol. 27, 283-285. doi: 10.1097/01.mph.0000164865.70522.d7 
Anuradha, S., Chatterjee, A., Bajaj, J., Singh, N. P., Agarwal, S. K., and Kaur, R. (2000). Trichosporon beigelii peritonitis in a HIV-positive patient on continuous ambulatory peritoneal dialysis. J. Assoc. Physicians India 48, $1022-1024$.

Arabatzis, M., Abel, P., Kanellopoulou, M., Adamou, D., AlexandrouAthanasoulis, H., Stathi, A., et al. (2014). Sequence-based identification, genotyping and EUCAST antifungal susceptibilities of Trichosporon clinical isolates from Greece. Clin. Microbiol. Infect. 20, 777-783. doi: 10.1111/1469-0691.12501

Arendrup, M. C., Boekhout, T., Akova, M., Meis, J. F., Cornely, O. A., Lortholary, O., et al. (2014). ESCMID/ECMM joint clinical guidelines for the diagnosis and management of rare invasive yeast infections. Clin. Microbiol. Infect. 20(Suppl .3), 76-98. doi: 10.1111/1469-0691.12360

Arikan, S., and Hasçelik, G. (2002). Comparison of NCCLS microdilution method and Etest in antifungal susceptibility testing of clinical Trichosporon asahii isolates. Diagn. Microbiol. Infect. Dis. 43, 107-111. doi: 10.1016/S07328893(02)00376-0

Asada, N., Uryu, H., Koseki, M., Takeuchi, M., Komatsu, M., and Matsue, K. (2006). Successful treatment of breakthrough Trichosporon asahii fungemia with voriconazole in a patient with acute myeloid leukemia. Clin. Infect. Dis. 43, e39-e41. doi: 10.1086/505970

Basiri, K., Meidani, M., Rezaie, F., Soheilnader, S., and Fatehi, F. (2012). A rare case of Trichosporon brain abscess, successfully treated with surgical excision and antifungal agents. Neurol. Neurochir. Pol. 46, 92-95. doi: 10.5114/ninp.2012.27180

Bassetti, M., Bisio, F., Di Biagio, A., Pierri, I., Balocco, M., Soro, O., et al. (2004). Trichosporon asahii infection treated with caspofungin combined with liposomal amphotericin B. J. Antimicrob. Chemother. 54, 575-577. doi: $10.1093 / \mathrm{jac} / \mathrm{dkh} 337$

Basu, S., Tilak, R., and Kumar, A. (2015). Multidrug-resistant Trichosporon: an unusual fungal sepsis in preterm neonates. Pathog. Glob. Health 109, 202-206. doi: 10.1179/2047773215Y.0000000019

Bayramoglu, G., Sonmez, M., Tosun, I., Aydin, K., and Aydin, F. (2008). Breakthrough Trichosporon asahii fungemia in neutropenic patient with acute leukemia while receiving caspofungin. Infection 36, 68-70. doi: 10.1007/s15010007-6278-6

Biasoli, M. S., Carlson, D., Chiganer, G. J., Parodi, R., Greca, A., Tosello, M. E., et al. (2008). Systemic infection caused by Trichosporon asahii in a patient with liver transplant. Med. Mycol. 46, 719-723. doi: 10.1080/13693780802232928

Campbell, C. K., Payne, A. L., Teall, A. J., Brownell, A., and Mackenzie, D. W. (1985). Cryptococcal latex antigen test positive in patient with Trichosporon beigelii infection. Lancet 2, 43-44. doi: 10.1016/S0140-6736(85)90093-5

Canales, M. A., Sevilla, J., Ojeda Gutierrez, E., and Hernández Navarro, F. (1998). Successful treatment of Trichosporon beigelii pneumonia with itraconazole. Clin. Infect. Dis. 26, 999-1000. doi: 10.1086/517648

Capoor, M. R., Gupta, D. K., Verma, P. K., and Sachdeva, H. C. (2015). Rare yeasts causing fungemia in immunocompromised and haematology patients: case series from Delhi. Indian J. Med. Microbiol. 33, 576-579. doi: 10.4103/02550857.167320

Cawley, M. J., Braxton, G. R., Haith, L. R., Reilly, K. J., Guilday, R. E., and Patton, M. L. (2000). Trichosporon beigelii infection: experience in a regional burn center. Burns J. 26, 483-486. doi: 10.1016/S0305-4179(99) 00181-3

Chagas-Neto, T. C., Chaves, G. M., Melo, A. S. A., and Colombo, A. L. (2009). Bloodstream infections due to Trichosporon spp.: species distribution, Trichosporon asahii genotypes determined on the basis of ribosomal DNA intergenic spacer 1 sequencing, and antifungal susceptibility testing. J. Clin. Microbiol. 47, 1074-1081. doi: 10.1128/JCM.01614-08

Chaitanya, V., Lakshmi, B. S., Kumar, A. C. V., Reddy, M. H. K., Ram, R., and Kumar, V. S. (2015). Disseminated Trichosporon infection in a renal transplant recipient. Transpl. Infect. Dis. 17, 605-609. doi: 10.1111/tid.12412

Chakrabarti, A., Marhawa, R. K., Mondal, R., Trehan, A., Gupta, S., Rao Raman, D. S. V., et al. (2002). Generalized lymphadenopathy caused by Trichosporon asahii in a patient with Job's syndrome. Med. Mycol. 40, 83-86. doi: $10.1080 / \mathrm{mmy} \cdot 40.1 .83 .86$

Chang, S. E., Kim, K. J., Lee, W. S., Choi, J. H., Sung, K. J., Moon, K. C., et al. (2003). A case of Trichosporon cutaneum folliculitis and septicaemia. Clin. Exp. Dermatol. 28, 37-38. doi: 10.1046/j.1365-2230.2003.01136.x
Chan-Tack, K. M. (2005). Fatal Trichosporon asahii septicemia in a Guatemalan farmer with acute lymphoblastic leukemia. South. Med. J. 98, 954-955. doi: 10.1097/01.smj.0000177350.91609.ea

Chaumentin, G., Boibieux, A., Piens, M. A., Douchet, C., Buttard, P., Bertrand, J. L., et al. (1996). Trichosporon inkin endocarditis: short-term evolution and clinical report. Clin. Infect. Dis. 23, 396-397. doi: 10.1093/clinids/23. 2.396

Chen, J., Chen, F., Wang, Y., Yang, L.-Y., Miao, M., Han, Y., et al. (2014). Use of combination therapy to successfully treat breakthrough Trichosporon asahii infection in an acute leukemia patient receiving voriconazole. Med. Mycol. Case Rep. 6, 55-57. doi: 10.1016/j.mmcr.2014.09.003

Chen, Y. T., Yang, W. C., Chen, T. W., and Lin, C. C. (2013). Trichosporon mucoides peritonitis in a continuous ambulatory peritoneal dialysis patient. Perit. Dial. Int. J. 33, 341-342. doi: 10.3747/pdi.2012.00146

Chitasombat, M. N., Kofteridis, D. P., Jiang, Y., Tarrand, J., Lewis, R. E., and Kontoyiannis, D. P. (2012). Rare opportunistic (non-Candida, nonCryptococcus) yeast bloodstream infections in patients with cancer. J. Infect. 64, 68-75. doi: 10.1016/j.jinf.2011.11.002

Chitra, A. K., Verghese, S., Fernandez, M., Mohan, A., Abraham, A., and Methew, T. (2002). Trichosporonosis due to Trichosporon beigelli in two hospitalized patients. Indian J. Pathol. Microbiol. 45, 337-339.

Cho, O., Matsukura, M., and Sugita, T. (2015). Molecular evidence that the opportunistic fungal pathogen Trichosporon asahii is part of the normal fungal microbiota of the human gut based on rRNA genotyping. Int. J. Infect. Dis. 39, 87-88. doi: 10.1016/j.ijid.2015.09.009

Chowdhary, A., Ahmad, S., Khan, Z. U., Doval, D. C., and Randhawa, H. S. (2004). Trichosporon asahii as an emerging etiologic agent of disseminated trichosporonosis: a case report and an update. Indian J. Med. Microbiol. 22, $16-22$.

Colombo, A. L., Padovan, A. C. B., and Chaves, G. M. (2011). Current knowledge of Trichosporon spp. and Trichosporonosis. Clin. Microbiol. Rev. 24, 682-700. doi: 10.1128/CMR.00003-11

Crowther, K. S., Webb, A. T., and McWhinney, P. H. (2003). Trichosporon inkin peritonitis in a patient on continuous ambulatory peritoneal dialysis returning from the Caribbean. Clin. Nephrol. 59, 69-70. doi: 10.5414/CNP59069

David, C., Martin, D. B., Deng, A., and Cooper, J. Z. (2008). Disseminated Trichosporon inkin and Histoplasma capsulatum in a patient with newly diagnosed AIDS. J. Am. Acad. Dermatol. 59, S13-S15. doi: 10.1016/j.jaad.2007.08.027

de Almeida Júnior, J. N., Figueiredo, D. S. Y., Toubas, D., Del Negro, G. M. B., Motta, A. L., Rossi, F., et al. (2014). Usefulness of matrix-assisted laser desorption ionisation-time-of-flight mass spectrometry for identifying clinical Trichosporon isolates. Clin. Microbiol. Infect. 20, 784-790. doi: 10.1111/14690691.12502

de Oliveira Silva, R. B., Fusco-Almeida, A. M., Matsumoto, M. T., Baeza, L. C., Benaducci, T., and Mendes-Giannini, M. J. S. (2008). Genetic diversity and antifungal susceptibility testing of Trichosporon asahii isolated of Intensive Care Units patients. Braz. J. Microbiol. Publ. Braz. Soc. Microbiol. 39, 585-592. doi: 10.1590/S1517-83822008000300033

De Pauw, B., Walsh, T. J., Donnelly, J. P., Stevens, D. A., Edwards, J. E., Calandra, T., et al. (2008). Revised definitions of invasive fungal disease from the European Organization for Research and Treatment of Cancer/Invasive Fungal Infections Cooperative Group and the National Institute of Allergy and Infectious Diseases Mycoses Study Group (EORTC/MSG) Consensus Group. Clin. Infect. Dis. 46, 1813-1821. doi: 10.1086/588660

De Saedeleer, B., Sennesael, J., Van der Niepen, P., and Verbeelen, D. (1994). Intraperitoneal fluconazole therapy for Trichosporon cutaneum peritonitis in continuous ambulatory peritoneal dialysis. Nephrol. Dial. Transplant. 9, 1658-1659.

Ebright, J. R., Fairfax, M. R., and Vazquez, J. A. (2001). Trichosporon asahii, a non-Candida yeast that caused fatal septic shock in a patient without cancer or neutropenia. Clin. Infect. Dis. 33, E28-E30. doi: 10.1086/322640

Erer, B., Galimberti, M., Lucarelli, G., Giardini, C., Polchi, P., Baronciani, D., et al. (2000). Trichosporon beigelii: a life-threatening pathogen in immunocompromised hosts. Bone Marrow Transplant. 25, 745-749. doi: $10.1038 /$ sj.bmt. 1702231

Espinel-Ingroff, A. (2003). In vitro antifungal activities of anidulafungin and micafungin, licensed agents and the investigational triazole posaconazole as 
determined by NCCLS methods for 12,052 fungal isolates: review of the literature. Rev. Iberoam. Micol. 20, 121-136.

Fadhil, R. A., Al-Thani, H., Al-Maslamani, Y., and Ali, O. (2011). Trichosporon fungal arteritis causing rupture of vascular anastamosis after commercial kidney transplantation: a case report and review of literature. Transplant. Proc. 43, 657-659. doi: 10.1016/j.transproceed.2011.01.082

Fagundes Júnior, A. A., Carvalho, R. T., Focaccia, R., Fernandez, J. G., Araújo, H. B. N., Strabelli, T. M. V., et al. (2008). [Trichosporon asahii an emerging etiologic agent of fungal infection and colonization in heart failure patients in intensive care unit: case report and literature review]. Rev. Bras. Ter. Intensiva 20, 106-109. doi: 10.1590/S0103-507X2008000100018

Fanci, R., Pecile, P., Martinez, R. L., Fabbri, A., and Nicoletti, P. (1997). Amphotericin B treatment of fungemia due to unusual pathogens in neutropenic patients: report of two cases. J. Chemother. Florence Italy 9, 427-430. doi: 10.1179/joc.1997.9.6.427

Fanfair, R. N., Heslop, O., Etienne, K., Rainford, L., Roy, M., Gade, L., et al. (2013). Trichosporon asahii among intensive care unit patients at a medical center in Jamaica. Infect. Control Hosp. Epidemiol. 34, 638-641. doi: 10.1086/670633

Fekkar, A., Brun, S., D’Ussel, M., Uzunov, M., Cracco, C., Dhédin, N., et al. (2009). Serum cross-reactivity with Aspergillus galactomannan and cryptococcal antigen during fatal disseminated Trichosporon dermatis infection. Clin. Infect. Dis. 49, 1457-1458. doi: 10.1086/644499

Fournier, S., Pavageau, W., Feuillhade, M., Deplus, S., Zagdanski, A.-M., Verola, O., et al. (2002). Use of voriconazole to successfully treat disseminated Trichosporon asahii infection in a patient with acute myeloid leukaemia. Eur. J. Clin. Microbiol. Infect. Dis. 21, 892-896.

Gabriel, F., Noel, T., and Accoceberry, I. (2011). Fatal invasive trichosporonosis due to Trichosporon loubieri in a patient with T-lymphoblastic lymphoma. Med. Mycol. 49, 306-310. doi: 10.3109/13693786.2010.525758

Ghiasian, S. A., Maghsood, A. H., and Mirhendi, S. H. (2006). Disseminated, fatal Trichosporon asahii infection in a bone marrow transplant recipient. J. Microbiol. Immunol. Infect. 39, 426-429.

Girmenia, C., Pagano, L., Martino, B., D’Antonio, D., Fanci, R., Specchia, G., et al. (2005). Invasive infections caused by Trichosporon species and Geotrichum capitatum in patients with hematological malignancies: a retrospective multicenter study from Italy and review of the literature. J. Clin. Microbiol. 43, 1818-1828. doi: 10.1128/JCM.43.4.1818-1828.2005

Gökahmetoğlu, S., Nedret Koç, A., Güneş, T., and Cetin, N. (2002). Case reports. Trichosporon mucoides infection in three premature newborns. Mycoses 45, 123-125. doi: 10.1046/j.1439-0507.2002.00736.x

Gold, J. W., Poston, W., Mertelsmann, R., Lange, M., Kiehn, T., Edwards, F., et al. (1981). Systemic infection with Trichosporon cutaneum in a patient with acute leukemia: report of a case. Cancer 48, 2163-2167.

Gomes, M. Z. R., Mulanovich, V. E., Jiang, Y., Lewis, R. E., and Kontoyiannis, D. P. (2014). Incidence density of invasive fungal infections during primary antifungal prophylaxis in newly diagnosed acute myeloid leukemia patients in a tertiary cancer center, 2009 to 2011. Antimicrob. Agents Chemother. 58, 865-873. doi: 10.1128/AAC.01525-13

Gonul, S., Gedik, S., Ozturk, B. T., Bakbak, B., Koktekir, B. E., Okudan, S., et al. (2015). Postoperative fungal endophthalmitis caused by Trichosporon asahii treated with voriconazole. Arq. Bras. Oftalmol. 78, 252-254. doi: 10.5935/00042749.20150065

Grauer, M. E., Bokemeyer, C., Bautsch, W., Freund, M., and Link, H. (1994). Successful treatment of a Trichosporon beigelii septicemia in a granulocytopenic patient with amphotericin B and granulocyte colony-stimulating factor. Infection 22, 283-286. doi: 10.1007/BF01739918

Gross, J. W., and Kan, V. L. (2008). Trichosporon asahii infection in an advanced AIDS patient and literature review. AIDS Lond. Engl. 22, 793-795. doi: 10.1097/QAD.0b013e3282f51ecc

Guého, E., Improvisi, L., de Hoog, G. S., and Dupont, B. (1994). Trichosporon on humans: a practical account. Mycoses 37, 3-10. doi: 10.1111/j.14390507.1994.tb00277.x

Gunn, S. R., Reveles, X. T., Hamlington, J. D., Sadkowski, L. C., Johnson-Pais, T. L., and Jorgensen, J. H. (2006). Use of DNA sequencing analysis to confirm fungemia due to Trichosporon dermatis in a pediatric patient. J. Clin. Microbiol. 44, 1175-1177. doi: 10.1128/JCM.44.3.1175-1177.2006

Guo, L.-N., Xiao, M., Kong, F., Chen, S. C.-A., Wang, H., Sorrell, T. C., et al. (2011). Three-locus identification, genotyping, and antifungal susceptibilities of medically important Trichosporon species from China. J. Clin. Microbiol. 49, 3805-3811. doi: 10.1128/JCM.00937-11

Hadley, S., Martinez, J. A., McDermott, L., Rapino, B., and Snydman, D. R. (2002). Real-time antifungal susceptibility screening aids management of invasive yeast infections in immunocompromised patients. J. Antimicrob. Chemother. 49, 415-419. doi: 10.1093/jac/49.2.415

Hajjeh, R. A., and Blumberg, H. M. (1995). Bloodstream infection due to Trichosporon beigelii in a burn patient: case report and review of therapy. Clin. Infect. Dis. 20, 913-916. doi: 10.1093/clinids/20.4.913

Hara, S., Yokote, T., Oka, S., Akioka, T., Kobayashi, K., Hirata, Y., et al. (2007). Endophthalmitis due to Trichosporon beigelii in acute leukemia. Int. J. Hematol. 85, 415-417. doi: 10.1532/IJH97.06228

Hazirolan, G., Canton, E., Sahin, S., and Arikan-Akdagli, S. (2013). Headto-head comparison of inhibitory and fungicidal activities of fluconazole, itraconazole, voriconazole, posaconazole, and isavuconazole against clinical isolates of Trichosporon asahii. Antimicrob. Agents Chemother. 57, 4841-4847. doi: 10.1128/AAC.00850-13

Heslop, O. D., Nyi Nyi, M.-P., Abbott, S. P., Rainford, L. E., Castle, D. M., and Coard, K. C. M. (2011). Disseminated trichosporonosis in a burn patient: meningitis and cerebral abscess due to Trichosporon asahii. J. Clin. Microbiol. 49, 4405-4408. doi: 10.1128/JCM.05028-11

Hickey, P. W., Sutton, D. A., Fothergill, A. W., Rinaldi, M. G., Wickes, B. L., Schmidt, H. J., et al. (2009). Trichosporon mycotoxinivorans, a novel respiratory pathogen in patients with cystic fibrosis. J. Clin. Microbiol. 47, 3091-3097. doi: 10.1128/JCM.00460-09

Higgins, E. M., Layton, D. M., Arya, R., Salisbury, J., and du Vivier, A. W. (1994). Disseminated Trichosporon beigelii infection in an immunosuppressed child. J. R. Soc. Med. 87, 292-293.

Hiramatsu, Y., Maeda, Y., Fujii, N., Saito, T., Nawa, Y., Hara, M., et al. (2008). Use of micafungin versus fluconazole for antifungal prophylaxis in neutropenic patients receiving hematopoietic stem cell transplantation. Int. J. Hematol. 88, 588-595. doi: 10.1007/s12185-008-0196-y

Hirschi, S., Letscher-Bru, V., Pottecher, J., Lannes, B., Jeung, M. Y., Degot, T., et al. (2012). Disseminated Trichosporon mycotoxinivorans, Aspergillus fumigatus, and Scedosporium apiospermum coinfection after lung and liver transplantation in a cystic fibrosis patient. J. Clin. Microbiol. 50, 4168-4170. doi: 10.1128/JCM.01928-12

Hosokawa, K., Yamazaki, H., Mochizuki, K., Ohata, K., Ishiyama, K., Hayashi, T. et al. (2012). Successful treatment of Trichosporon fungemia in a patient with refractory acute myeloid leukemia using voriconazole combined with liposomal amphotericin B. Transpl. Infect. Dis. 14, 184-187. doi: 10.1111/j.13993062.2011.00670.x

Hosoki, K., Iwamoto, S., Kumamoto, T., Azuma, E., and Komada, Y. (2008). Early detection of breakthrough trichosporonosis by serum PCR in a cord blood transplant recipient being prophylactically treated with voriconazole. J. Pediatr. Hematol. Oncol. 30, 917-919. doi: 10.1097/MPH.0b013e3181864aa7

Hsiao, G. H., Chang, C. C., Chen, J. C., Kuo, W. L., and Huang, S. F. (1994). Trichosporon beigelii fungemia with cutaneous dissemination. A case report and literature review. Acta Derm. Venereol. 74, 481-482.

Hung, C. C., Chang, S. C., Chen, Y. C., Tien, H. F., and Hsieh, W. C. (1995). Trichosporon beigelii fungemia in patients with acute leukemia: report of three cases. J. Formos. Med. Assoc. 94, 127-131.

Issarachaikul, R., Lertwannawit, O., Detporntewan, P., Uaprasert, N., Plongla, R., Shuangshoti, S., et al. (2014). Catheter-related bloodstream infections caused by Trichosporon species. Southeast Asian J. Trop. Med. Public Health 45, 421-429.

Itoh, T., Hosokawa, H., Kohdera, U., Toyazaki, N., and Asada, Y. (1996). Disseminated infection with Trichosporon asahii. Mycoses 39, 195-199. doi: 10.1111/j.1439-0507.1996.tb00124.x

Iturrieta-González, I. A., Padovan, A. C. B., Bizerra, F. C., Hahn, R. C., and Colombo, A. L. (2014). Multiple species of Trichosporon produce biofilms highly resistant to triazoles and amphotericin B. PLoS ONE 9:e109553. doi: 10.1371/journal.pone.0109553

Izumi, K., Hisata, Y., and Hazama, S. (2009). A rare case of infective endocarditis complicated by Trichosporon asahii fungemia treated by surgery. Ann. Thorac. Cardiovasc. Surg. 15, 350-353.

Jian, D. Y., Yang, W. C., Chen, T. W., and Lin, C. C. (2008). Trichosporon asahii following polymicrobial infection in peritoneal dialysis-associated peritonitis. Perit. Dial. 28, 100-101. 
Kahana, D. D., Cass, O., Jessurun, J., Schwarzenberg, S. J., Sharp, H., and Khan, K. (2003). Sclerosing cholangitis associated with trichosporon infection and natural killer cell deficiency in an 8-year-old girl. J. Pediatr. Gastroenterol. Nutr. 37, 620-623. doi: 10.1097/00005176-200311000-00022

Karabay, O., Madariaga, M. G., Kocoglu, E., Ince, N., and Kandirali, E. (2006). Trichosporon asahii fungemia in a patient with non-hematological malignancy. Jpn. J. Infect. Dis. 59, 129-131.

Karapinar, D. Y., Karadaş, N., Yazici, P., Polat, S. H., and Karapinar, B. (2014). Trichosporon asahii, sepsis, and secondary hemophagocytic lymphohistiocytosis in children with hematologic malignancy. Pediatr. Hematol. Oncol. 31, 282-284. doi: 10.3109/08880018.2013.851754

Kataoka-Nishimura, S., Akiyama, H., Saku, K., Kashiwa, M., Mori, S., Tanikawa, S., et al. (1998). Invasive infection due to Trichosporon cutaneum in patients with hematologic malignancies. Cancer 82, 484-487.

Kaufman, D., Boyle, R., Hazen, K. C., Patrie, J. T., Robinson, M., and Donowitz, L. G. (2001). Fluconazole prophylaxis against fungal colonization and infection in preterm infants. N. Engl. J. Med. 345, 1660-1666. doi: 10.1056/NEJMoa 010494

Kendirli, T., Ciftçi, E., Ince, E., Oncel, S., Dalgiç, N., Güriz, H., et al. (2006). Successful treatment of Trichosporon mucoides infection with lipid complex amphotericin B and 5-fluorocytosine. Mycoses 49, 251-253. doi: 10.1111/j.1439-0507.2006.01223.x

Kim, J. C., Kim, Y. S., Park, C. S., Kang, J. M., Kim, B. N., Woo, J. H., et al. (2001). A case of disseminated Trichosporon beigelii infection in a patient with myelodysplastic syndrome after chemotherapy. J. Korean Med. Sci. 16, 505-508. doi: $10.3346 / \mathrm{jkms} .2001 .16 .4 .505$

Kim, K.-W., Ha, K.-Y., Kim, M.-S., Choi, S.-M., and Lee, J.-S. (2008). Postoperative Trichosporon asahii spondylodiscitis after open lumbar discectomy: a case report. Spine 33, E116-E120. doi: 10.1097/brs.0b013e3181642a7c

Kim, Y. J., Kim, S. I., Kim, Y. R., Park, Y. M., Park, Y. J., and Kang, M. W. (2007). Successful treatment of septic shock with purpura fulminans caused by Trichosporon asahii in an immunocompetent patient. Ann. Clin. Lab. Sci. 37, 366-369.

Kontoyiannis, D. P., Torres, H. A., Chagua, M., Hachem, R., Tarrand, J. J., Bodey, G. P., et al. (2004). Trichosporonosis in a tertiary care cancer center: risk factors, changing spectrum and determinants of outcome. Scand. J. Infect. Dis. 36, 564-569. doi: 10.1080/00365540410017563

Kouppari, G., Stephanidis, K., Zaphiropoulou, A., Siapera, D., and Deliyianni, V. (1997). Trichosporon beigelii peritonitis in a child on continuous ambulatory peritoneal dialysis. Clin. Microbiol. Infect. Dis. 3, 509-510. doi: 10.1111/j.14690691.1997.tb00297.x

Koyanagi, T., Nishida, N., Osabe, S., Imamura, Y., Yamamoto, S., Shichiji, A., et al. (2006). Autopsy case of disseminated Trichosporon inkin infection identified with molecular biological and biochemical methods. Pathol. Int. 56, 738-743. doi: 10.1111/j.1440-1827.2006.02040.x

Krcmery, V. Jr., Mateicka, F., Kunová, A., Spánik, S., Gyarfás, J., Sycová, Z., et al. (1999). Hematogenous trichosporonosis in cancer patients: report of 12 cases including 5 during prophylaxis with itraconazol. Support. Care Cancer 7, 39-43. doi: $10.1007 / \mathrm{s} 005200050221$

Kudo, K., Terui, K., Sasaki, S., Kamio, T., Sato, T., and Ito, E. (2011). Voriconazole for both successful treatment of disseminated Trichosporon asahii infection and subsequent cord blood transplantation in an infant with acute myelogenous leukemia. Bone Marrow Transplant. 46, 310-311. doi: 10.1038/bmt.2010.96

Kumar, A., Udayakumaran, S., Babu, R., Rajamma, B. M., Prakash, A., Panikar, D., et al. (2015). Trichosporon asahii infection presenting as chronic meningoventriculitis and intra ventricular fungal ball: a case report and literature review. Mycoses 58, 99-103. doi: 10.1111/myc. 12282

Kustimur, S., Kalkanci, A., Caglar, K., Dizbay, M., Aktas, F., and Sugita, T. (2002). Nosocomial fungemia due to Trichosporon asteroides: firstly described bloodstream infection. Diagn. Microbiol. Infect. Dis. 43, 167-170. doi: $10.1016 /$ S0732-8893(02)00385-1

Lacasse, A., and Cleveland, K. O. (2009). Trichosporon mucoides fungemia in a liver transplant recipient: case report and review. Transpl. Infect. Dis. 11, 155-159. doi: 10.1111/j.1399-3062.2008.00355.x

Lascaux, A. S., Bouscarat, F., Descamps, V., Casalino, E., Picard-Dahan, C., Crickx, B., et al. (1998). [Cutaneous manifestations during disseminated trichosporonosis in an AIDS patient]. Ann. Dermatol. Vénéréologie 125, 111-113.
Leblond, V., Saint-Jean, O., Datry, A., Lecso, G., Frances, C., Bellefiqh, S., et al. (1986). Systemic infections with Trichosporon beigelii (cutaneum). Report of three new cases. Cancer 58, 2399-2405.

Lemes, R. M. L., Lyon, J. P., Moreira, L. M., and de Resende, M. A. (2010). Antifungal susceptibility profile of Trichosporon isolates: correlation between CLSI and etest methodologies. Braz. J. Microbiol. 41, 310-315. doi: 10.1590/S1517-83822010000200008

Liao, Y., Hartmann, T., Zheng, T., Yang, R.-Y., Ao, J.-H., and Wang, W.-L. (2012). Breakthrough trichosporonosis in patients receiving echinocandins: case report and literature review. Chin. Med. J. (Engl.) 125, 2632-2635.

Liao, Y., Lu, X., Yang, S., Luo, Y., Chen, Q., and Yang, R. (2015). Epidemiology and Outcome of Trichosporon Fungemia: a review of 185 reported cases from 1975 to 2014. Open Forum Infect. Dis. 2:ofv141. doi: 10.1093/ofid/ofv141

Lo Passo, C., Pernice, I., Celeste, A., Perdichizzi, G., and Todaro-Luck, F. (2001). Transmission of Trichosporon asahii oesophagitis by a contaminated endoscope. Mycoses 44, 13-21. doi: 10.1046/j.1439-0507.2001.00614.x

Lopes, J. O., Alves, S. H., Benevenga, J. P., Rosa, A. C., and Gomez, V. C. (1994). Trichosporon beigelii peritonitis associated with continuous ambulatory peritoneal dialysis. Rev. Inst. Med. Trop. São Paulo 36, 121-123. doi: 10.1590/S0036-46651994000200005

Lopes, J. O., Alves, S. H., Klock, C., Oliveira, L. T., and Dal Forno, N. R. (1997). Trichosporon inkin peritonitis during continuous ambulatory peritoneal dialysis with bibliography review. Mycopathologia 139, 15-18. doi: 10.1023/A:1006870017725

Lopes, J. O., Silva, C. B., Kmohan, C., Salla, A., and Righi, R. A. (1995). [Trichosporon beigelii peritonitis in a child during treatment by continuous ambulatory peritoneal dialysis]. J. Pediatr. (Rio J.) 71, 341-343. doi: 10.2223/JPED.803

Macêdo, D. P. C., de Oliveira, N. T., da Silva, V. K. A., de Almeida Farias, A. M., de Lima Neto, R. G., Wilheim, A. B., et al. (2011). Trichosporon inkin Esophagitis: an uncommon disease in a patient with Pulmonary Cancer. Mycopathologia 171, 279-283. doi: 10.1007/s11046-010-9367-5

Madariaga, M. G., Tenorio, A., and Proia, L. (2003). Trichosporon inkin peritonitis treated with caspofungin. J. Clin. Microbiol. 41, 5827-5829. doi: 10.1128/JCM.41.12.5827-5829.2003

Maheshwari, A., Stromquist, C. I., Pereda, L., and Emmanuel, P. J. (2004). Mixed infection with unusual fungi and staphylococcal species in two extremely premature neonates. J. Perinatol. 24, 324-326. doi: 10.1038/sj.jp.7211077

Marty, F. M., Barouch, D. H., Coakley, E. P., and Baden, L. R. (2003). Disseminated trichosporonosis caused by Trichosporon loubieri. J. Clin. Microbiol. 41, 5317-5320. doi: 10.1128/JCM.41.11.5317-5320.2003

Mathews, M. S., and Prabhakar, S. (1995). Chronic meningitis caused by Trichosporon beigelii in India. Mycoses 38, 125-126. doi: 10.1111/j.14390507.1995.tb00034.x

Matsue, K., Uryu, H., Koseki, M., Asada, N., and Takeuchi, M. (2006). Breakthrough trichosporonosis in patients with hematologic malignancies receiving micafungin. Clin. Infect. Dis. 42, 753-757. doi: 10.1086/500323

Meguro-Hashimoto, A., Takatoku, M., Ohmine, K., Toshima, M., Mori, M., Nagai, T., et al. (2006). The usefulness of magnetic resonance imaging (MRI) for disseminated trichosporosis of the gastrocnemius muscles. J. Infect. 53, e135-e138. doi: 10.1016/j.jinf.2005.11.026

Mekha, N., Sugita, T., Ikeda, R., Nishikawa, A., Autthateinchai, R., Poonwan, N., et al. (2010). Genotyping and antifungal drug susceptibility of the pathogenic yeast Trichosporon asahii isolated from Thai patients. Mycopathologia 169, 67-70. doi: 10.1007/s11046-009-9225-5

Melez, K. A., Cherry, J., Sanchez, C., Ettinger, R. B., and Walsh, T. J. (1995). Successful outpatient treatment of Trichosporon beigelii peritonitis with oral fluconazole. Pediatr. Infect. Dis. J. 14, 1110-1113. doi: 10.1097/00006454199512000-00020

Menezes, E. A., de Sousa Marinho, J. A., Angelo, M. R. F., da Conceição dos Santos Oliveira Cunha, M., Cunha, F. A., and de Vasconcelos Júnior, A. A (2012). Isolation and antifungal susceptibility testing of Trichosporon asahii in Ceará, Brazil. Rev. Inst. Med. Trop. São Paulo 54, 1-3. doi: 10.1590/S003646652012000100001

Metin, D. Y., Hilmioglu-Polat, S., Hakim, F., Inci, R., and Tumbay, E. (2005). Evaluation of the microdilution, Etest and disk diffusion methods for antifungal susceptibility testing of clinical strains of Trichosporon spp. J. Chemother. Florence Italy 17, 404-408. doi: 10.1179/joc.2005.17.4.404 
Meyer, M. H., Letscher-Bru, V., Waller, J., Lutz, P., Marcellin, L., and Herbrecht, R. (2002). Chronic disseminated Trichosporon asahii infection in a leukemic child. Clin. Infect. Dis. 35, e22-e25. doi: 10.1086/340983

Miró, O., Sacanella, E., Nadal, P., Lluch, M. M., Nicolás, J. M., Millá, J., et al. (1994). Trichosporon beigelii fungemia and metastatic pneumonia in a trauma patient. Eur. J. Clin. Microbiol. Infect. Dis. 13, 604-606. doi: 10.1007/BF019 71314

Miralles, A., Quiroga, J., Farinola, T., Obi, C., Saura, E., Fontanillas, C., et al. (1994). Recurrent Trichosporon beigelii endocarditis after aortic valve replacement. Cardiovasc. Surg. Lond. Engl. 2, 119-123.

Miura, Y., Kaneko, M., Nishizawa, M., Okamoto, K., Hirai, M., Kaneko, H., et al. (2007). Breakthrough infection of Trichosporon asahii in a patient with chronic lymphocytic leukemia. Int. J. Hematol. 85, 177-178. doi: 10.1532/IJH97.06220

Montoya, A. M., Sánchez González, A., Palma-Nicolás, J. P., Gómez-Treviño, A., González, J. G., and González, G. M. (2015). Genotyping, extracellular compounds, and antifungal susceptibility testing of Trichosporon asahii isolated from Mexican patients. Med. Mycol. 53, 505-511. doi: 10.1093/mmy/myv009

Mooty, M. Y., Kanj, S. S., Obeid, M. Y., Hassan, G. Y., and Araj, G. F. (2001). A case of Trichosporon beigelii endocarditis. Eur. J. Clin. Microbiol. Infect. Dis. 20, 139-142. doi: 10.1007/PL00011245

Moretti-Branchini, M. L., Fukushima, K., Schreiber, A. Z., Nishimura, K., Papaiordanou, P. M., Trabasso, P., et al. (2001). Trichosporon species infection in bone marrow transplanted patients. Diagn. Microbiol. Infect. Dis. 39, 161-164. doi: 10.1016/S0732-8893(01)00215-2

Nachbaur, D., Angelova, O., Orth-Höller, D., Ditlbacher, A., Lackner, M., Auberger, J., et al. (2015). Primary antifungal prophylaxis with micafungin in patients with haematological malignancies: real-life data from a retrospective single-centre observational study. Eur. J. Haematol. 94, 258-264. doi: 10.1111/ejh.12426

Nasu, K., Akizuki, S., Yoshiyama, K., Kikuchi, H., Higuchi, Y., and Yamamoto, S. (1994). Disseminated Trichosporon infection. A case report and immunohistochemical study. Arch. Pathol. Lab. Med. 118, 191-194.

Negi, V., Sharma, M., Juyal, D., Kotian, S., and Sharma, N. (2015). Disseminated trichosporonosis due to Trichosporon asahii in a diabetic patient. Indian J. Pathol. Microbiol. 58, 246-248. doi: 10.4103/0377-4929.155333

Nettles, R. E., Nichols, L. S., Bell-McGuinn, K., Pipeling, M. R., Scheel, P. J. Jr., and Merz, W. G. (2003). Successful treatment of Trichosporon mucoides infection with fluconazole in a heart and kidney transplant recipient. Clin. Infect. Dis. 36, E63-E66. doi: 10.1086/367665

Nobrega de Almeida Júnior, J., Buccheri de Oliveira, R., Duarte, A., Lopes Motta, A., Rossi, F., Sachiko Yamamoto de Figueiredo, D., et al. (2015). Trichosporon inkin as an emergent pathogen in patients with severe Pemphigus. JAMA Dermatol. 151, 642-645. doi: 10.1001/jamadermatol.2014.5462

Nucci, M., Pulcheri, W., Spector, N., Maiolino, A., Caiuby, M. J., Maceira, J., et al. (1992). Cutaneous involvement of systemic fungal infections in neutropenic patients. Haematologica 77, 522-523.

O'Gorman, C., McMullan, R., Webb, C. H., and Bedi, A. (2006). Trichosporon Asahii. blood-stream infection in a non-cancer patient receiving combination Antifungal Therapy. Ulster Med. J. 75, 226-227.

Odero, V., Galán-Sánchez, F., García-Agudo, L., García-Tapia, A. M., GuerreroLozano, I., and Rodríguez-Iglesias, M. A. (2015). [Fungemia due to Trichosporon asahii in a patient with hematological malignancy]. Rev. Iberoam. Micol. 32, 59-61. doi: 10.1016/j.riam.2013.09.001

Ogura, M., Kagami, S., Nakao, M., Kono, M., Kanetsuna, Y., and Hosoya, T. (2012). Fungal granulomatous interstitial nephritis presenting as acute kidney injury diagnosed by renal histology including PCR assay. Clin. Kidney J. 5, 459-462. doi: $10.1093 / \mathrm{ckj} / \mathrm{sfs} 103$

Ozkaya-Parlakay, A., Karadag-Oncel, E., Cengiz, A. B., Kara, A., Yigit, A., Gucer, S., et al. (2016). Trichosporon asahii sepsis in a patient with pediatric malignancy. J. Microbiol. Immunol. Infect. 49, 146-149. doi: 10.1016/j.jmii.2013.01.003

Padhi, S., Dash, M., Pattanaik, S., and Sahu, S. (2014). Fungemia due to Trichosporon mucoides in a diabetes mellitus patient: a rare case report. Indian J. Med. Microbiol. 32, 72-74. doi: 10.4103/0255-0857.124324

Panagopoulou, P., Evdoridou, J., Bibashi, E., Filioti, J., Sofianou, D., Kremenopoulos, G., et al. (2002). Trichosporon asahii: an unusual cause of invasive infection in neonates. Pediatr. Infect. Dis. J. 21, 169-170. doi: 10.1097/00006454-200202000-00018

Paphitou, N. I., Ostrosky-Zeichner, L., Paetznick, V. L., Rodriguez, J. R., Chen, E., and Rex, J. H. (2002). In vitro antifungal susceptibilities of Trichosporon species.
Antimicrob. Agents Chemother. 46, 1144-1146. doi: 10.1128/AAC.46.4.11441146.2002

Park, H. J., Park, M., Han, M., Nam, B. H., Koh, K. N., Im, H. J., et al. (2014). Efficacy and safety of micafungin for the prophylaxis of invasive fungal infection during neutropenia in children and adolescents undergoing allogeneic hematopoietic SCT. Bone Marrow Transplant. 49, 1212-1216. doi: 10.1038/bmt.2014.136

Pérard, B., Rougeron, A., Favre, S., Accoceberry, I., Vigouroux, S., Mohr, C., et al. (2015). Trichosporon faecale invasive infection in a patient with severe aplastic anemia: efficacy of voriconazole and liposomal amphotericin B before neutrophil recovery. Med. Mycol. Case Rep. 9, 12-14. doi: 10.1016/j.mmcr.2015.06.003

Pereira, D. N., Nader, S. S., Nader, P., Martins, P. G., Furlan, S. P., and Hentges, C. R. (2009). Disseminated Trichosporon spp infection in preterm newborns: a case report. J. Pediatr. (Rio J.) 85, 459-461.

Pfaller, M. A., Diekema, D. J., Gibbs, D. L., Newell, V. A., Bijie, H., Dzierzanowska, D., et al. (2009). Results from the ARTEMIS DISK Global Antifungal Surveillance Study, 1997 to 2007: 10.5-year analysis of susceptibilities of noncandidal yeast species to fluconazole and voriconazole determined by CLSI standardized disk diffusion testing. J. Clin. Microbiol. 47, 117-123. doi: 10.1128/JCM.01747-08

Piwoz, J. A., Stadtmauer, G. J., Bottone, E. J., Weitzman, I., Shlasko, E., and Cummingham-Rundles, C. (2000). Trichosporon inkin lung abscesses presenting as a penetrating chest wall mass. Pediatr. Infect. Dis. J. 19, 1025-1027. doi: 10.1097/00006454-200010000-00023

Ramos, J. M., Cuenca-Estrella, M., Gutierrez, F., Elia, M., and Rodriguez-Tudela, J. L. (2004). Clinical case of endocarditis due to Trichosporon inkin and antifungal susceptibility profile of the organism. J. Clin. Microbiol. 42, 2341-2344. doi: 10.1128/JCM.42.5.2341-2344.2004

Reddy, B. T., Torres, H. A., and Kontoyiannis, D. P. (2002). Breast implant infection caused by Trichosporon beigelii. Scand. J. Infect. Dis. 34, 143-144. doi: $10.1080 / 00365540110026895$

Rieger, C., Geiger, S., Herold, T., Nickenig, C., and Ostermann, H. (2007). Breakthrough infection of Trichosporon asahii during posaconazole treatment in a patient with acute myeloid leukaemia. Eur. J. Clin. Microbiol. Infect. Dis. 26, 843-845. doi: 10.1007/s10096-007-0366-5

Rodrigues Gda, S., de Faria, R. R., Guazzelli, L. S., Oliveira Fde, M., and Severo, L. C. (2006). [Nosocomial infection due to Trichosporon asahii: clinical revision of 22 cases]. Rev. Iberoam. Micol. 23, 85-89. doi: 10.1016/S1130-1406(06)70019-5

Rodriguez-Tudela, J. L., Diaz-Guerra, T. M., Mellado, E., Cano, V., Tapia, C., Perkins, A., et al. (2005). Susceptibility patterns and molecular identification of Trichosporon species. Antimicrob. Agents Chemother. 49, 4026-4034. doi: 10.1128/AAC.49.10.4026-4034.2005

Rodriguez-Tudela, J. L., Gomez-Lopez, A., Alastruey-Izquierdo, A., Mellado, E., Bernal-Martinez, L., and Cuenca-Estrella, M. (2007). Genotype distribution of clinical isolates of Trichosporon asahii based on sequencing of intergenic spacer 1. Diagn. Microbiol. Infect. Dis. 58, 435-440. doi: 10.1016/j.diagmicrobio.2007.03.001

Salazar, G. E., and Campbell, J. R. (2002). Trichosporonosis, an unusual fungal infection in neonates. Pediatr. Infect. Dis. J. 21, 161-165. doi: 10.1097/00006454-200202000-00016

Servonnet, A., Bourgault, M., Trueba, F., Sarret, D., and Nicand, E. (2010). [Disseminated Trichosporon asahii infection]. Ann. Biol. Clin. (Paris) 68, 363-366.

Shang, S.-T., Yang, Y.-S., and Peng, M.-Y. (2010). Nosocomial Trichosporon asahii fungemia in a patient with secondary hemochromatosis: a rare case report. J. Microbiol. Immunol. Infect. 43, 77-80. doi: 10.1016/S1684-1182(10) 60012-6

Sidarous, M. G., O’Reilly, M. V., and Cherubin, C. E. (1994). A case of Trichosporon beigelii endocarditis 8 years after aortic valve replacement. Clin. Cardiol. 17, 215-219.

Sklair-Levy, M., Libson, Y., Lossos, I. S., and Bugomolsky-Yahalom, V. (1998). Splenic calcifications caused by Trichosporon beigelli infection: CT and ultrasound demonstration. Eur. Radiol. 8, 922-924. doi: $10.1007 / \mathrm{s} 003300050488$

Slocumb, R. W., Elner, S. G., and Hall, E. F. (2010). Chronic postoperative fungal endophthalmitis caused by trichosporon asahii. Retin. Cases Brief Rep. 4, 366-367. doi: 10.1097/ICB.0b013e3181b5ef61 
Songcharoen, S., Cleary, J. D., Jenkins, J., and DeShazo, M. (2011). T. asahii pulmonary infection as a complication of TNF-inhibitor and steroids: posaconazole pharmacotherapy and risk analysis. J. Miss. State Med. Assoc. 52, 339-343.

Spánik, S., Kollár, T., Gyarfás, J., Kunová, A., and Krcméry, V. (1995). Successful treatment of catheter-associated fungemia due to Candida krusei and Trichosporon beigelii in a leukemic patient receiving prophylactic itraconazole. Eur. J. Clin. Microbiol. Infect. Dis. 14, 148-149. doi: 10.1007/BF02111878

Spirn, M. J., Roth, D. B., Yarian, D. L., and Green, S. N. (2003). Postoperative fungal endophthalmitis caused by Trichosporon beigelii resistant to amphotericin B. Retina Phila. Pa 23, 404-405. doi: 10.1097/00006982-200306000-00020

Still, J. M., Orlet, K., and Law, E. J. (1994). Trichosporon beigelii septicaemia in a burn patient. Burns J. 20, 467-468. doi: 10.1016/0305-4179(94)90045-0

Sugita, T., Nakajima, M., Ikeda, R., Matsushima, T., and Shinoda, T. (2002). Sequence analysis of the ribosomal DNA intergenic spacer 1 regions of Trichosporon species. J. Clin. Microbiol. 40, 1826-1830. doi: 10.1128/JCM.40.5.1826-1830.2002

Sun, W., Su, J., Xu, S., and Yan, D. (2012). Trichosporon asahii causing nosocomial urinary tract infections in intensive care unit patients: genotypes, virulence factors and antifungal susceptibility testing. J. Med. Microbiol. 61, 1750-1757. doi: 10.1099/jmm.0.049817-0

Suzuki, K., Nakase, K., Kyo, T., Kohara, T., Sugawara, Y., Shibazaki, T., et al. (2010). Fatal Trichosporon fungemia in patients with hematologic malignancies. Eur. J. Haematol. 84, 441-447. doi: 10.1111/j.1600-0609.2010.01410.x

Sweet, D., and Reid, M. (1998). Disseminated neonatal Trichosporon beigelii infection: successful treatment with liposomal amphotericin B. J. Infect. 36, 120-121. doi: 10.1016/S0163-4453(98)93630-1

Taj-Aldeen, S. J., Al-Ansari, N., El Shafei, S., Meis, J. F., Curfs-Breuker, I., Theelen, B., et al. (2009). Molecular identification and susceptibility of Trichosporon species isolated from clinical specimens in Qatar: isolation of Trichosporon dohaense Taj-Aldeen, Meis \& Boekhout sp. nov. J. Clin. Microbiol. 47, 1791-1799. doi: 10.1128/JCM.02222-08

Takamura, S., Oono, T., Kanzaki, H., and Arata, J. (1999). Disseminated Trichosporonosis with Trichosporon asahii. Eur. J. Dermatol. 9, 577-579.

Tanyildiz, H. G., Yesil, S., Toprak, S., Candir, M. O., and Sahin, G. (2015). Two case presentations infected by Trichosporon asahii and treated with Voriconazole Successfully. Case Rep. Infect. Dis. 2015:651315. doi: 10.1155/2015/651315

Taverna, C. G., Córdoba, S., Murisengo, O. A., Vivot, W., Davel, G., and BoscoBorgeat, M. E. (2014). Molecular identification, genotyping, and antifungal susceptibility testing of clinically relevant Trichosporon species from Argentina. Med. Mycol. 52, 356-366. doi: 10.1093/mmy/myt029

Thibeault, R., Champagne, M., de Repentigny, L., Fournet, J.-C., Tapiero, B., Moghrabi, A., et al. (2008). Fatal disseminated Trichosporon asahii infection in a child with acute lymphoblastic leukemia. Can. J. Infect. Dis. Med. Microbiol. 19, 203-205. doi: 10.1155/2008/787689

Thompson, G. R. III, Wiederhold, N. P., Sutton, D. A., Fothergill, A., and Patterson, T. F. (2009). In vitro activity of isavuconazole against Trichosporon, Rhodotorula, Geotrichum, Saccharomyces and Pichia species. J. Antimicrob. Chemother. 64, 79-83. doi: 10.1093/jac/dkp138

Tian, H. H., Tan, S. M., and Tay, K. H. (2007). Delayed fungal infection following augmentation mammoplasty in an immunocompetent host. Singapore Med. J. 48, 256-258.

Tsai, M.-J., Chang, W.-A., Tsai, K.-B., Chen, H.-C., Hwang, J.-J., and Huang, M.-S. (2011). Probable invasive pulmonary trichosporonosis in a diabetic patient. Am. J. Respir. Crit. Care Med. 184, 982. doi: 10.1164/rccm.201101-0144IM

Tsai, M. S., Yang, Y. L., Wang, A. H., Wang, L. S., Lu, D. C. T., Liou, C. H., et al. (2012). Susceptibilities to amphotericin B, fluconazole and voriconazole of Trichosporon clinical isolates. Mycopathologia 174, 121-130. doi: 10.1007/s11046-012-9525-Z

Tsuji, Y., Tokimatsu, I., Sugita, T., Nozaki, M., Kobayashi, D., Imai, K., et al. (2008). Quantitative PCR assay used to monitor serum Trichosporon asahii DNA concentrations in disseminated trichosporonosis. Pediatr. Infect. Dis. J. 27, 1035-1037. doi: 10.1097/INF.0b013e318179260d

Vashishtha, V. M., Mittal, A., and Garg, A. (2012). A fatal outbreak of Trichosporon asahii sepsis in a neonatal intensive care Unit. Indian Pediatr. 49, 745-747. doi: 10.1007/s13312-012-0137-y
Viscomi, S. G., Mortelé, K. J., Cantisani, V., Glickman, J., and Silverman, S. G. (2004). Fatal, complete splenic infarction and hepatic infection due to disseminated Trichosporon beigelii infection: CT findings. Abdom. Imaging 29, 228-230. doi: 10.1007/s00261-003-0099-6

Walia, H., Tucci, V. T., Greene, J. N., Tordilla-Wadia, J., Kelty, P., and Walia, S. (2009). A case of endogenous trichosporon endophthalmitis treated with micafungin and voriconazole. J. Glob. Infect. Dis. 1, 71-74. doi: 10.4103/0974777X.52987

Walsh, T. J., Melcher, G. P., Rinaldi, M. G., Lecciones, J., McGough, D. A., Kelly, P., et al. (1990). Trichosporon beigelii, an emerging pathogen resistant to amphotericin B. J. Clin. Microbiol. 28, 1616-1622.

Walsh, T. J., Newman, K. R., Moody, M., Wharton, R. C., and Wade, J. C. (1986). Trichosporonosis in patients with neoplastic disease. Medicine (Baltimore) 65, 268-279. doi: 10.1097/00005792-198607000-00005

Wang, H. Y., and Lin, J. L. (1999). Trichosporon beigelii fungaemia in a patient with haemodialysis. Nephrol. Dial. Transplant. 14, 2017-2018. doi: 10.1093/ndt/14.8.2017

Wolf, D. G., Falk, R., Hacham, M., Theelen, B., Boekhout, T., Scorzetti, G., et al. (2001). Multidrug-resistant Trichosporon asahii infection of nongranulocytopenic patients in three intensive care units. J. Clin. Microbiol. 39, 4420-4425. doi: 10.1128/JCM.39.12.4420-4425.2001

Wynne, S. M., Kwon-Chung, K. J., Shea, Y. R., Filie, A. C., Varma, A., Lupo, P., et al. (2004). Invasive infection with Trichosporon inkin in 2 siblings with chronic granulomatous disease. J. Allergy Clin. Immunol. 114, 1418-1424. doi: 10.1016/j.jaci.2004.07.066

Yang, M.-F., Gao, H.-N., and Li, L.-J. (2014). Afatal case of Trichosporon asahii fungemia and pneumonia in a kidney transplant recipient during caspofungin treatment. Ther. Clin. Risk Manag. 10, 759-762. doi: 10.2147/TCRM.S67299

Yang, Y.-L., Liu, Y.-W., Chen, H.-T., Tsai, M.-S., Chu, W.-L., and Lo, H.-J. (2013). Genotype analysis based on intergenic spacer 1 sequences of Trichosporon asahii collected in Taiwan. Med. Mycol. 51, 880-883. doi: 10.3109/13693786.2013.800240

Yildiran, A., Kücüködük, S., Saniç, A., Belet, N., and Güvenli, A. (2003). Disseminated Trichosporon asahii infection in a preterm. Am. J. Perinatol. 20, 269-271. doi: 10.1055/s-2003-42337

Yoss, B. S., Sautter, R. L., and Brenker, H. J. (1997). Trichosporon beigelii, a new neonatal pathogen. Am. J. Perinatol. 14, 113-117. doi: 10.1055/s-2007994109

Zaragoza, O., Mesa-Arango, A. C., Gómez-López, A., Bernal-Martínez, L., Rodríguez-Tudela, J. L., and Cuenca-Estrella, M. (2011). Process analysis of variables for standardization of antifungal susceptibility testing of nonfermentative yeasts. Antimicrob. Agents Chemother. 55, 1563-1570. doi: 10.1128/AAC.01631-10

Zhang, E., Sugita, T., Tsuboi, R., Yamazaki, T., and Makimura, K. (2011). The opportunistic yeast pathogen Trichosporon asahii colonizes the skin of healthy individuals: analysis of 380 healthy individuals by age and gender using a nested polymerase chain reaction assay. Microbiol. Immunol. 55, 483-488. doi: 10.1111/j.1348-0421.2011.00341.x

Zuo, Q., Dong, L., Mu, W., Zhou, L., Hu, T., and Zhang, H. (2015). Trichosporon asahii infection after total knee arthroplasty: a case report and review of the literature. Can. J. Infect. Dis. Med. Microbiol. 26, 47-51. doi: $10.1155 / 2015 / 458670$

Conflict of Interest Statement: JN was supported by grants from Fundação de Amparo à Pesquisa do Estado de São Paulo (2011/08911-0). CH received a grant from Pfizer for the development of a MALDI-TOF approach for the identification of Trichosporon clinical isolates. $\mathrm{CH}$ received fees for oral speaker from Astellas and Merk Sharp and Dohme. $\mathrm{CH}$ received travel grants from Pfizer, Astellas, and Merk Sharp and Dohme.

Copyright (c) 2016 de Almeida Júnior and Hennequin. This is an open-access article distributed under the terms of the Creative Commons Attribution License (CC BY). The use, distribution or reproduction in other forums is permitted, provided the original author(s) or licensor are credited and that the original publication in this journal is cited, in accordance with accepted academic practice. No use, distribution or reproduction is permitted which does not comply with these terms. 